Electronic Supplementary Information to

\title{
Revealing Protein Aggregates Under Thapsigargin-Induced ER Stress Using an ER-Targeted Thioflavin
}

Peter Verwilst, ${ }^{\dagger+}$ Kyutae Kim, ${ }^{\S}$ Kyoung Sunwoo, ${ }^{\dagger}$ Hye-Ri Kim, ${ }^{\S}$ Chulhun Kang ${ }^{\S *}$ and Jong Seung $\mathrm{Kim}^{\dagger *}$

$\dagger$ Department of Chemistry, Korea University, Seoul 02841, Korea

$\S$ School of East-West Medical Science, Kyung Hee University, Yongin 17104, Korea 


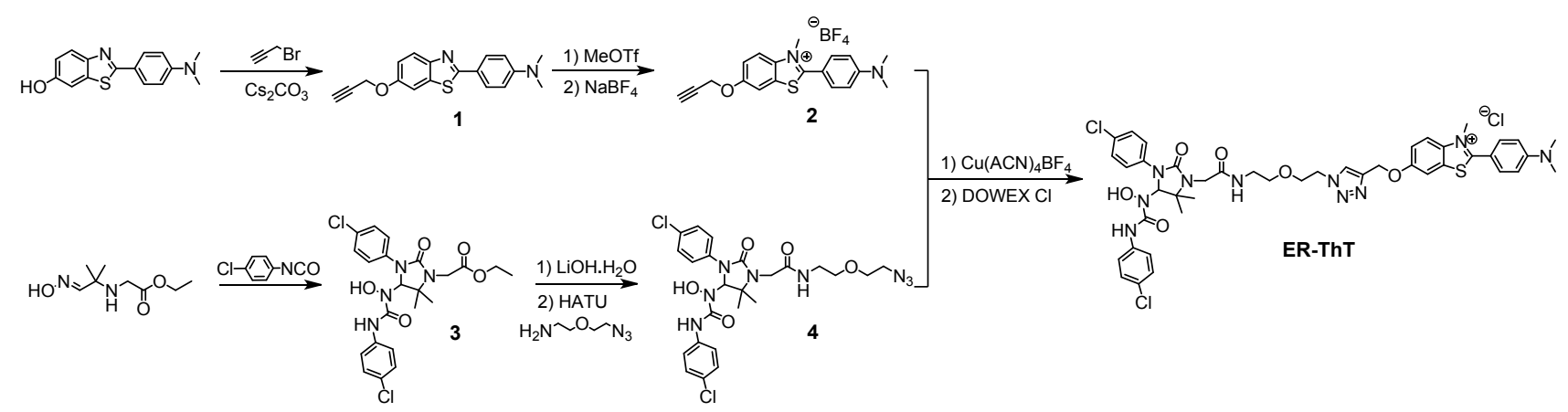

Scheme. S1: Synthesis of ER-ThT

\section{Synthesis of $N, N$-dimethyl-4-[6-(2-propyn-1-yloxy)-1,3-benzothiazol-2-yl]aniline (1).}

To a suspension of $1.2 \mathrm{~g}$ (4.44 mmol) 2-[4-(dimethylamino)phenyl]-1,3-benzothiazol-6-ol ${ }^{\mathrm{S} 1}$ and $4.8 \mathrm{~g}$ (14.65 mmol) $\mathrm{Cs}_{2} \mathrm{CO}_{3}$ in $10 \mathrm{~mL}$ anhydrous DMF, $1.3 \mathrm{~mL}(8.88 \mathrm{mmol})$ of an $80 \mathrm{wt} \%$ solution of propargyl bromide in toluene is added. The resulting mixture was stirred overnight at room temperature, after which $100 \mathrm{~mL}$ of DCM was added and the solids were removed by filtration over Celite ${ }^{\circledR}$. The filtrate was washed with water $(3 \times 50 \mathrm{~mL})$ and brine $(1 \times 50 \mathrm{~mL})$ and the organic layer was dried over $\mathrm{Na}_{2} \mathrm{SO}_{4}$. Column chromatography (silica, $\mathrm{DCM} /$ Methanol 95/5 $\rightarrow$ 90/10) yielded $250 \mathrm{mg}(0.81 \mathrm{mmol}, 18 \%)$ of $N, N$-dimethyl-4-[6-(2propyn-1-yloxy)-1,3-benzothiazol-2-yl]aniline (1). ${ }^{1} \mathrm{H}$ NMR $\left(500 \mathrm{MHz}, \mathrm{CDCl}_{3}\right): \delta 7.94(\mathrm{~d}$, $J=9.0 \mathrm{~Hz}, 2 \mathrm{H}), 7.92(\mathrm{~d}, J=8.9 \mathrm{~Hz}, 1 \mathrm{H}), 7.44(\mathrm{~d}, J=2.6 \mathrm{~Hz}, 1 \mathrm{H}), 7.13(\mathrm{dd}, J=8.9 \mathrm{~Hz}$, $J=2.6 \mathrm{~Hz}, 1 \mathrm{H}), 6.77(\mathrm{~d}, J=9.0 \mathrm{~Hz}, 2 \mathrm{H}), 4.78(\mathrm{~d}, J=2.4 \mathrm{~Hz}, 2 \mathrm{H}), 3.08(\mathrm{~s}, 6 \mathrm{H}), 2.58$ (t, $J=2.4 \mathrm{~Hz}, 1 \mathrm{H}) \mathrm{ppm} .{ }^{13} \mathrm{C} \mathrm{NMR}\left(125 \mathrm{MHz}, \mathrm{CDCl}_{3}\right): \delta 167.15,154.99,152.03,135.56,128.65$, $128.61,122.75,115.61,111.79,106.12,104.40,78.46,77.82,56.55,40.24$ ppm. MS(ESI): $\mathrm{C}_{18} \mathrm{H}_{16} \mathrm{~N}_{2} \mathrm{OS}[\mathrm{M}+\mathrm{H}]^{+}, m / z$ calcd 309.11 , found 309.05 .

\section{Synthesis of 2-[4-(dimethylamino)phenyl]-3-methyl-6-(2-propyn-1-yloxy)-1,3-} benzothiazol-3-ium tetrafluoroborate (2). To a solution of $50 \mathrm{mg}(0.16 \mathrm{mmol}) \mathbf{1}$ in $4 \mathrm{~mL}$ anhydrous DCM, $70 \mu \mathrm{L}(0.62 \mathrm{mmol})$ methyl trifluoromethanesulfonate is added. The resulting mixture was stirred overnight at room temperature in the dark, after which $50 \mathrm{~mL}$ of DCM was added and the precipitate was isolated using vacuum filtration and washed with cold diethyl ether $(2 \times 20 \mathrm{~mL})$ and dried in a vacuum oven. The resulting solids were redissolved in a minimal amount of $\mathrm{MeOH}$, after which $100 \mathrm{~mL}$ water was added. To the resulting solution, an excess of $\mathrm{NaBF}_{4}$ was added and the precipitate was isolated via vacuum filtration and dried in a vacuum oven. The solids were dissolved/suspended in $50 \mathrm{~mL}$ of acetone and filtrated. The filtrate was collected and evaporated, resulting in $41 \mathrm{mg}$ (0.10 mmol, 63\%) of 2-[4-(dimethylamino)phenyl]-3-methyl-6-(2-propyn-1-yloxy)-1,3benzothiazol-3-ium tetrafluoro-borate (2). ${ }^{1} \mathrm{H}$ NMR (500 MHz, $\mathrm{CD}_{3} \mathrm{CN}$ ): $\delta 7.96(\mathrm{~d}, J=9.3$ $\mathrm{Hz}, 1 \mathrm{H}), 7.77(\mathrm{~d}, J=2.6 \mathrm{~Hz}, 1 \mathrm{H}), 7.74(\mathrm{~d}, J=9.2 \mathrm{~Hz}, 2 \mathrm{H}), 7.49$ (dd, $J=9.3 \mathrm{~Hz}, J=2.6 \mathrm{~Hz}$, $1 \mathrm{H}), 6.95(\mathrm{~d}, J=9.2 \mathrm{~Hz}, 2 \mathrm{H}), 4.92(\mathrm{~d}, J=2.4 \mathrm{~Hz}, 2 \mathrm{H}), 4.18(\mathrm{~s}, 3 \mathrm{H}), 3.15(\mathrm{~s}, 6 \mathrm{H}), 2.95$ (t, $J=$ $2.4 \mathrm{~Hz}, 1 \mathrm{H})$ ppm. NMR (125 MHz, $\left.\mathrm{CD}_{3} \mathrm{CN}\right): \delta 173.61,158.09,155.05,136.64,133.02$, 130.71, 119.82, 118.41, 112.87, 111.74, 108.25, 78.57, 77.76, 57.48, 40.27, 39.05 ppm. MS(ESI): $\mathrm{C}_{19} \mathrm{H}_{19} \mathrm{~N}_{2} \mathrm{OS}[\mathrm{M}]^{+}, m / z$ calcd 323.12, found 323.00 . 
Synthesis of ethyl \{3-(4-chlorophenyl)-4-[\{[(4-chlorophenyl)amino]carbonyl\}(hydroxy)amino]-5,5-dimethyl-2-oxo-1-imidazolidinyl\}acetate (3). The ethyl ester was synthesized analogously to a reported procedure for the methyl ester. ${ }^{\mathrm{S} 2}$ A solution of $680 \mu \mathrm{L}(5.30 \mathrm{mmol})$ 4-chlorophenyl isocyanate in $2 \mathrm{~mL}$ dry THF was added dropwise to a solution of $500 \mathrm{mg}$ (2.65 mmol) ethyl $\{[(2 E)-2$-(hydroxyimino)-1,1-dimethylethyl $]$ amino $\}$ acetate in $12 \mathrm{~mL}$ dry THF. The resulting solution was stirred overnight at room temperature and then concentrated under reduced pressure. The product was crystallized from dichloromethane, collected by filtration, washed with diethyl ether and dried, resulting in $783 \mathrm{mg}(1.58 \mathrm{mmol}, 60 \%)$ of ethyl $\{3-(4-c h l o r o p h e n y l)-4-[\{[(4-c h l o r o p h e n y l) a m i n o]$ carbonyl $\}$ (hydroxy)amino]-5,5-dimethyl-2oxo-1-imidazolidinyl $\}$ acetate (3). ${ }^{1} \mathrm{H}$ NMR (500 MHz, DMSO- $\left.d_{6}\right): \delta 9.78$ (br. s, 1H), 9.27 (br. $\mathrm{s}, 1 \mathrm{H}), 7.71-7.62(\mathrm{~m}, 4 \mathrm{H}), 7.40-7.28(\mathrm{~m}, 4 \mathrm{H}), 6.08(\mathrm{~s}, 1 \mathrm{H}), 4.12(\mathrm{q}, J=7.0 \mathrm{~Hz}, 2 \mathrm{H}), 3.98(\mathrm{~s}$, $2 \mathrm{H}), 1.31(\mathrm{~s}, 3 \mathrm{H}), 1.26(\mathrm{~s}, 3 \mathrm{H}), 1.22(\mathrm{t}, J=7.0 \mathrm{~Hz}, 2 \mathrm{H}) \mathrm{ppm} .{ }^{13} \mathrm{C}$ NMR (125 MHz, DMSO$\left.d_{6}\right): \delta 169.96,157.04,156.00,138.52,138.49,128.82,128.74,126.90,126.83,120.59$, $120.27,74.81,60.95,59.16,41.37,26.94,19.55,14.54 \mathrm{ppm}$.

Synthesis of $N$-[2-(2-azidoethoxy)ethyl]-2-\{3-(4-chlorophenyl)-4-[\{[(4-chlorophenyl)amino] carbonyl\}(hydroxy)amino]-5,5-dimethyl-2-oxo-1-imidazolidinyl acetamide (4).

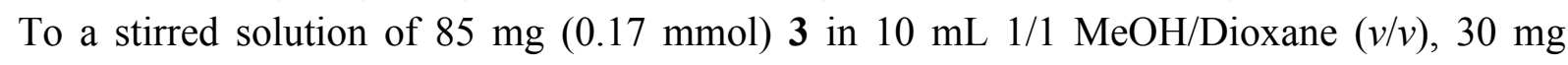
$(0.68 \mathrm{mmol}) \mathrm{LiOH} \cdot \mathrm{H}_{2} \mathrm{O}$ in $5 \mathrm{~mL}$ water was added and the resulting solution was stirred overnight. The $\mathrm{pH}$ of the solution was adjusted to $\mathrm{pH}=2$, using a $1 \mathrm{~N}$ solution of $\mathrm{HCl}$, and extracted with DCM $(5 \times 30 \mathrm{~mL})$. The organic layers were combined, dried over $\mathrm{Na}_{2} \mathrm{SO}_{4}$ and solvent was removed under reduced pressure, resulting in $64 \mathrm{mg}(0.14 \mathrm{mmol}, 79 \%)$ of the corresponding carboxylic acid that was used without further purification. $64 \mathrm{mg}$ of the thusly obtained compound was dissolved in $2 \mathrm{~mL}$ anhydrous DMF and $58 \mathrm{mg}(0.15 \mathrm{mmol})$ HATU was added while the solution was maintained at $0{ }^{\circ} \mathrm{C}$ for 30 minutes. The ice bath was removed and subsequently $20 \mathrm{mg}(0.15 \mathrm{mmol})$ 2-(2-azidoethoxy)ethanamine ${ }^{\mathrm{S} 3}$ and $70 \mu \mathrm{L}$ $(0.45 \mathrm{mmol})$ DIPEA were added, after which the solution was stirred in the dark at room temperature overnight. The solvent was removed under reduced pressure and the residue was purified using column chromatography (silica, DCM/Methanol 100/0 $\rightarrow 96 / 4$ ), to yield $41 \mathrm{mg}$ (0.07 mmol, 51\%) N-[2-(2-azidoethoxy)ethyl]-2-\{3-(4-chlorophenyl)-4-[\{[(4-chlorophenyl) amino]carbonyl (hydroxy)amino]-5,5-dimethyl-2-oxo-1-imidazolidinyl $\}$ acetamide (4). ${ }^{1} \mathrm{H}$ NMR $\left(500 \mathrm{MHz}, \mathrm{CD}_{3} \mathrm{CN}+\mathrm{DMSO}-d_{6}\right): \delta 9.95$ (br. s, $\left.1 \mathrm{H}\right), 8.51(\mathrm{~s}, 1 \mathrm{H}), 7.74(\mathrm{~d}, J=9.0 \mathrm{~Hz}$, 2H), $7.55(\mathrm{~d}, J=9.0 \mathrm{~Hz}, 2 \mathrm{H}), 7.35(\mathrm{~d}, J=9.0 \mathrm{~Hz}, 2 \mathrm{H}), 7.32$ (d, $J=9.0 \mathrm{~Hz}, 2 \mathrm{H}), 7.28$ (br. t, $J=5.4 \mathrm{~Hz}, 1 \mathrm{H}), 6.14(\mathrm{~s}, 1 \mathrm{H}), 4.00(\mathrm{~d}, J=17.5 \mathrm{~Hz}, 1 \mathrm{H}), 3.65(\mathrm{~d}, J=17.5 \mathrm{~Hz}, 1 \mathrm{H}), 3.62$ (t, $J=5.0 \mathrm{~Hz}, 2 \mathrm{H}), 3.54(\mathrm{t}, J=5.0 \mathrm{~Hz}, 2 \mathrm{H}), 3.46-3.29(\mathrm{~m}, 4 \mathrm{H}), 1.36(\mathrm{~s}, 3 \mathrm{H}), 1.30$ (s, 3H) ppm. ${ }^{13} \mathrm{C}$ NMR $\left(125 \mathrm{MHz}, \mathrm{CD}_{3} \mathrm{CN}+\mathrm{DMSO}-d_{6}\right): \delta 170.67,157.24,157.10,138.94,138.31,129.38$ ( $\times 2), 128.41,128.38,122.29,121.38,75.39,70.02,69.81,60.06,51.23,43.17,39.73,25.57$, 19.20 ppm. MS(ESI): $\mathrm{C}_{24} \mathrm{H}_{28}{ }^{35} \mathrm{Cl}_{2} \mathrm{~N}_{8} \mathrm{O}_{5}[\mathrm{M}+\mathrm{Na}]^{+}, \mathrm{m} / z$ calcd 601.15 , found 601.05 .

Synthesis of 6-\{[1-(2-\{2-[(\{3-(4-chlorophenyl)-4-[\{[(4-chlorophenyl)amino]-carbonyl\}(hydroxy)amino]-5,5-dimethyl-2-oxo-1-imidazolidinyl $\}$ acetyl)amino]ethoxy ethyl)-1H1,2,3-triazol-4-yl] methoxy\}-2-[4-(dimethylamino)phenyl]-3-methyl-1,3-benzothiazol-3ium chloride (ER-ThT). $41 \mathrm{mg}(0.07 \mathrm{mmol}) 4$ and $30 \mathrm{mg}(0.07 \mathrm{mmol}) \mathbf{2}$ are dissolved in $2 \mathrm{~mL}$ anhydrous DMF and argon gas is bubbled trough the solution for 30 minutes. To this 
solution $10 \mathrm{~mol} \% \mathrm{Cu}(\mathrm{ACN})_{4} \mathrm{BF}_{4}$ is added and the resulting mixture is stirred overnight in the dark at $40{ }^{\circ} \mathrm{C}$. The solvent in removed under reduced pressure and the residue is purified using column chromatography (silica, DCM/Methanol 96/4 $\rightarrow$ 90/10). The resulting $\mathrm{BF}_{4}^{-}{ }^{-}$salt is dissolved in $\mathrm{MeOH}$ and slowly eluted trough a Dowex ${ }^{\circledR}$ chloride column to yield the corresponding $\mathrm{Cl}^{-}$salt of ER-ThT (13.6 mg, $\left.14 \mathrm{mmol}, 20 \%\right) .{ }^{1} \mathrm{H} \mathrm{NMR}\left(500 \mathrm{MHz}, \mathrm{CD}_{3} \mathrm{CN}\right.$, $\mathrm{BF}_{4}{ }^{-}$salt): $\delta 9.22(\mathrm{~s}, 1 \mathrm{H}), 8.39(\mathrm{~s}, 1 \mathrm{H}), 7.99(\mathrm{~s}, 1 \mathrm{H}), 7.86(\mathrm{~d}, J=9.3 \mathrm{~Hz}, 1 \mathrm{H}), 7.71-7.66(\mathrm{~m}$, $5 \mathrm{H}), 7.51(\mathrm{~d}, J=8.8 \mathrm{~Hz}, 2 \mathrm{H}), 7.42(\mathrm{dd}, J=9.3 \mathrm{~Hz}, J=2.6 \mathrm{~Hz}, 1 \mathrm{H}), 7.25(\mathrm{~d}, J=9.0 \mathrm{~Hz}, 4 \mathrm{H})$, 7.10 (br. t, $J=5.5 \mathrm{~Hz}, 1 \mathrm{H}), 6.93(\mathrm{~d}, J=9.0 \mathrm{~Hz}, 2 \mathrm{H}), 6.17(\mathrm{~s}, 1 \mathrm{H}), 5.24(\mathrm{~s}, 2 \mathrm{H}), 4.52$ (dt, $J=5.5 \mathrm{~Hz}, J=5.0 \mathrm{~Hz}, 2 \mathrm{H}), 4.13(\mathrm{~s}, 3 \mathrm{H}), 4.09(\mathrm{~d}, J=17.4 \mathrm{~Hz}, 1 \mathrm{H}), 3.82(\mathrm{t}, J=5.0 \mathrm{~Hz}, 2 \mathrm{H})$, $3.65(\mathrm{~d}, J=17.4 \mathrm{~Hz}, 1 \mathrm{H}), 3.52-3.42(\mathrm{~m}, 2 \mathrm{H}), 3.35-3.24(\mathrm{~m}, 2 \mathrm{H}), 3.16(\mathrm{~s}, 6 \mathrm{H}), 1.33(\mathrm{~s}, 3 \mathrm{H})$, 1.30 (s, 3H) ppm. ${ }^{13} \mathrm{C}$ NMR (125 MHz, $\mathrm{CD}_{3} \mathrm{CN}, \mathrm{BF}_{4}{ }^{-}$salt): $\delta 173.15,171.23,159.04,157.50$, 156.92 , 155.08, 143.26, 138.91, 138.53, 138.27, 133.06, 130.73, 129.48, 129.45, 128.57, 128.42 , 126.07, 122.06, 121.64, 119.89, 112.93, 111.77, 107.94, 75.49, 70.00, 69.63, 63.10, 60.03, 51.18, 43.00, 40.35, 39.91, 39.07, 25.63, 19.39 ppm.MS(ESI, Cl- salt): $\mathrm{C}_{43} \mathrm{H}_{47}{ }^{35} \mathrm{Cl}_{2} \mathrm{~N}_{10} \mathrm{O}_{6} \mathrm{~S}[\mathrm{M}]^{+}, m / z$ calcd 901.28 , found 901.15 .

\section{Spectroscopic analysis of ER-ThT in solution}

A stock solution of ER-ThT was prepared in DMSO and diluted for solution experiments. The absorption and emission spectra were recorded on a UV-560 (JASCO) spectrophotometer and RF-5301PC spectrofluorometer (Shimadzu) equipped with a xenon lamp, respectively. Other information is available in the figure captions.

For preparation of the solutions containing proteins, protein stock solutions $(100 \mu \mathrm{g} / \mathrm{mL})$ were diluted in $10 \mathrm{mM}$ HEPES ( $\mathrm{pH} 7.4,150 \mathrm{mM} \mathrm{NaCl}$ ). For the reductive denaturation of proteins, a stock solution for DTT $(1 \mathrm{M})$ was diluted to adjust its concentration in a $10 \mathrm{mM}$ sodium phosphate buffer ( $\mathrm{pH} 7.0)$.

\section{Preparation of Liposomes}

Liposome preparation was based on an extrusion method using a $10 \mathrm{~mL}$ LIPEX ${ }^{\circledR}$ Thermobarrel Extruder (Transferra Nanosciences lnc., Burnaby, Canada), according to a modified procedure. Briefly, the lipid mixtures were dissolved in chloroform $(10 \mathrm{~mL})$ followed by vortex to assure homogenization of the mixture. Then, the solvent was removed by sequential application of a rotary evaporator and a vacuum pump to make the mixture a thin lipid film. To the obtained film, $10 \mathrm{~mL}$ of HEPES buffer (preheated, $\mathrm{pH} 7.2,150 \mathrm{mM}$ $\mathrm{NaCl}$ ) was added and vortexed 3 times ( 5 seconds each). The preheated temperature was maintained above the gel-lipid crystal transition temperature $\left(T_{c}\right)$ of the lipid which has the highest $\mathrm{T}_{\mathrm{c}}$ value $\left(-17,41\right.$, and $50{ }^{\circ} \mathrm{C}$ for DOPC, DPPC, and sphingomyelin, respectively). The resulting emulsion was loaded to the extruder equipment and pressured by $\mathrm{N}_{2}$ gas at 200 psi to pass through a set of filters ( 2 sheets of polycarbonate filters and 1 sheet of a polyester drain disk). The extrusion was repeated 10 times. The final volumes of the recovered solutions were approximately $9 \mathrm{~mL}$. The solutions were diluted to make the samples in the experiments. Other information is available in the relevant figure captions. 


\section{Cell Culture and Confocal Microscopy}

Human cervical cancer cells (HeLa) were cultured in DMEM (WelGene Inc., Seoul, Korea) supplemented with $10 \%$ fetal bovine serum (Gibco BRL), penicillin (100 U/mL), and streptomycin $(100 \mu \mathrm{g} / \mathrm{mL})$. The cells were plated on glass-bottomed dishes for confocal microscopy (SPL Life Sciences, Korea) and maintained in a humidified 5\% ( $v / v) \mathrm{CO}_{2} /$ air mixture at $37{ }^{\circ} \mathrm{C}$ for 24 hours. Fluorescence images were taken using a confocal laser scanning microscope (Zeiss LSM 510, Zeiss, Oberko, Germany). microscope (Zeiss LSM 510, Zeiss, Oberko, Germany). The imaging parameters for the microscopy were kept the same for all figures: $100 \mu \mathrm{m}$ pinhole, $100 \%$ laser power at $458 \mathrm{~nm}, 1.00$ amplifier gain and 700 detection gain. Other information is available in the figure captions.

\section{Western Blot}

A semi-dry blotter (Trans-Blot ${ }^{\circledR}$ SD Semi-Dry Electrophoretic Transfer Cell, Bio-Rad, Hercules, CA) was used for western blot experiments and the detailed procedure from the provider was followed with minor modifications. Briefly, protein samples were harvested on plates using RIPA buffer (20 mM Tris-HCl (pH 7.5), $150 \mathrm{mM} \mathrm{NaCl}, 1 \mathrm{mM} \mathrm{Na}{ }_{2}$ EDTA, $1 \mathrm{mM}$ EGTA, 1\% NP-40, 1\% sodium deoxycholate, $2.5 \mathrm{mM}$ sodium pyrophosphate, $1 \mathrm{mM} \beta-$ glycerophosphate, $1 \mathrm{mM} \mathrm{Na} \mathrm{VO}_{4} 1 \mu \mathrm{g} / \mathrm{mL}$ leupeptin.). Electrophoresis was performed using a $10 \%$ polyacrylamide gel and the amount of the protein sample per well was $10 \mu \mathrm{g}$, the blotting membrane was a nitrocellulose membrane. For the membrane blocking, a nonfat dried milk solution was used upon $1 \mathrm{~h}$ incubation at room temperature. Anti-BiP, anti-phospho PERK, anti-PERK, and anti-IRE1 antibodies were purchased from Cell Signaling Technology. Anti-phospho IRE1 antibody, secondary HRP-conjugated anti-antibody and anti-ATF6 antibodies were obtained from Abcam, Santa Cruz Biotechnology and Novus, respectively. For the internal standard, anti- $\beta$-actin (Santa Cruise Inc) was used. The immune-reactive protein bands on the gel were visualized by application of an enhanced chemiluminescence kit from the ATTO Corporation.

\section{Chemical chaperones, UPR inhibitors and the organelle trackers}

Thapsigargin was purchased from Abcam (Cambridge, MA, USA). sodium 4-phenylbutyrate (PBA) was purchased from BIOVISION (Milpitas, CA, USA). GSK2656157 was purchased from Santa Cruz Biotechnology (SantaCruz, CA, USA). Brefendin A (Bref. A), tauroursodeoxycholic acid (TUDCA), trimethylamine N-oxide (TMAO), Ceapin-A7 and

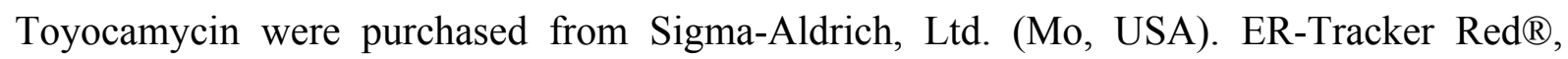
Mito-tracker®, and Lyso-tracker ${ }^{\circledR}$ were purchased from Invitrogen, Co. (Oregon, USA). 


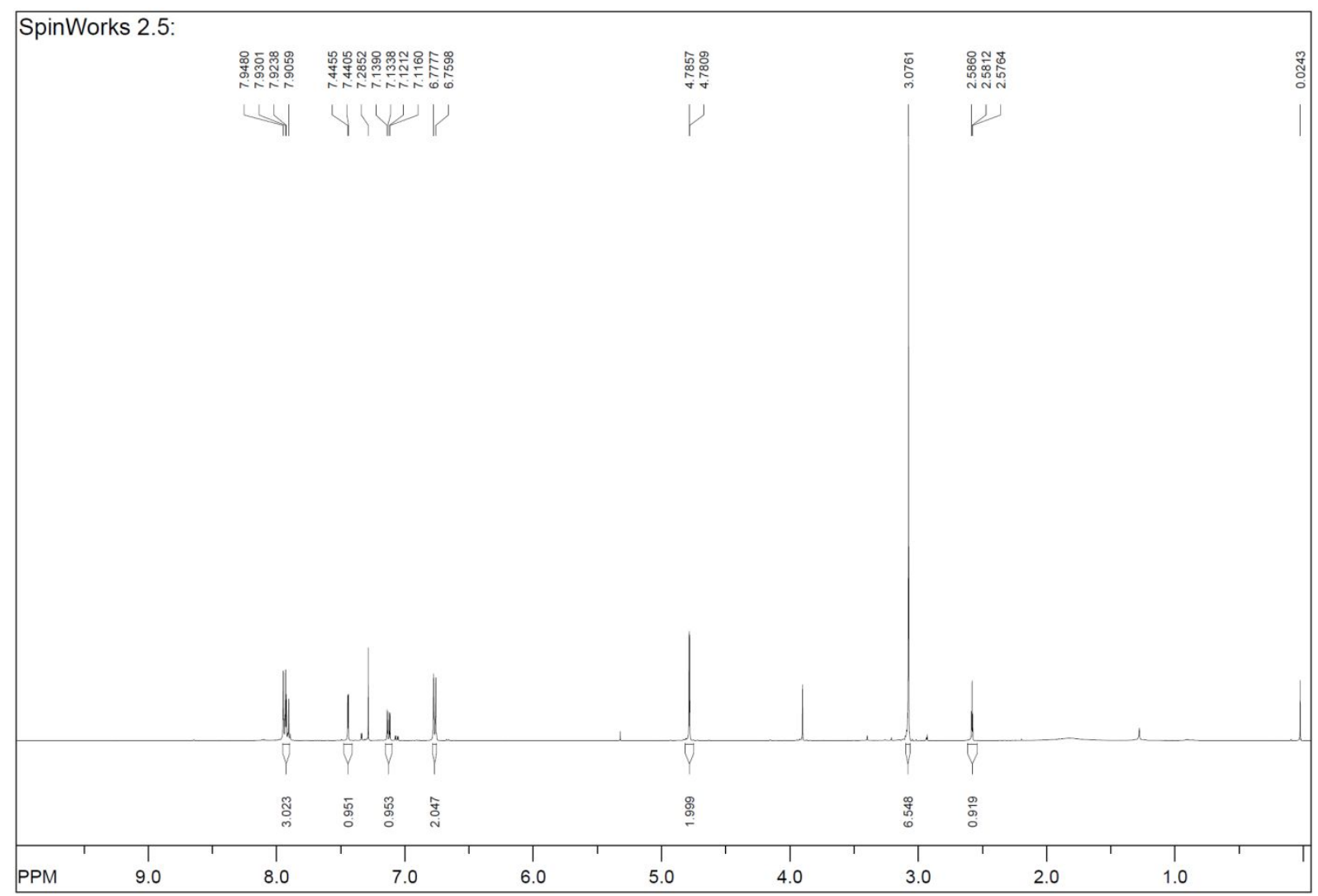

Figure S1. ${ }^{1} \mathrm{H}$ NMR spectrum of $\mathbf{1}$.

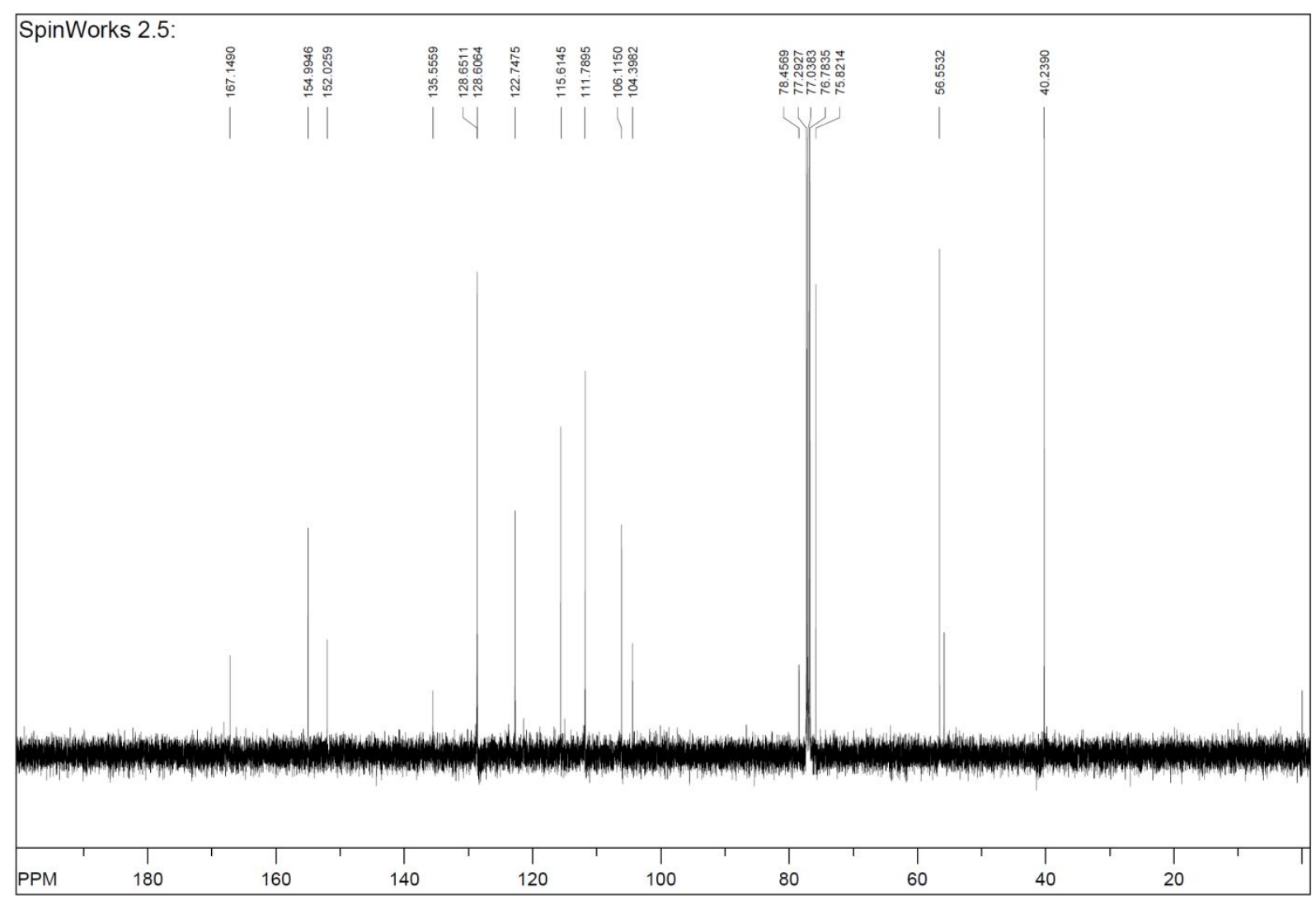

Figure S2. ${ }^{13} \mathrm{C}$ NMR spectrum of $\mathbf{1}$. 


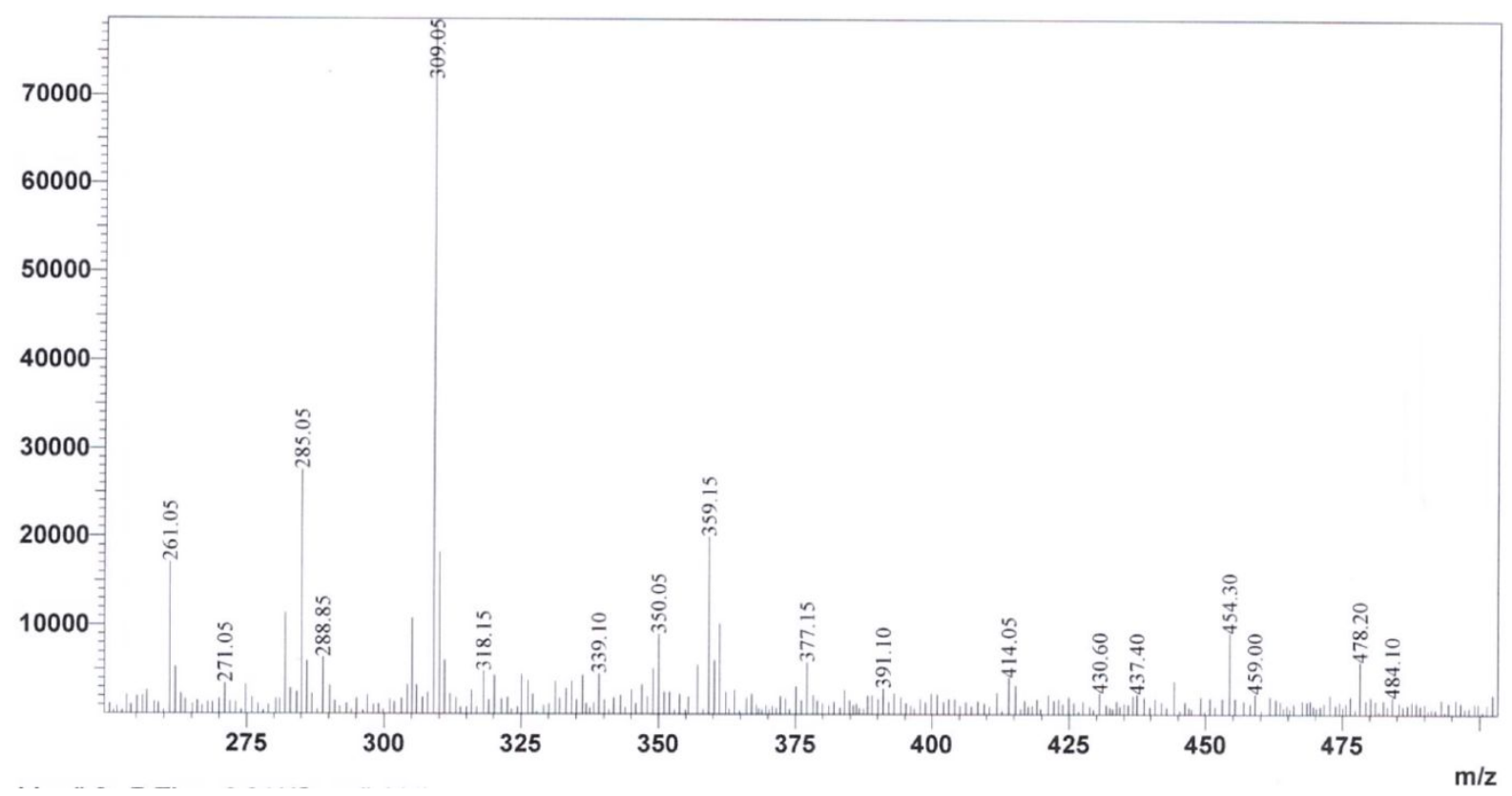

Figure S3. ESI-MS spectrum of 1.

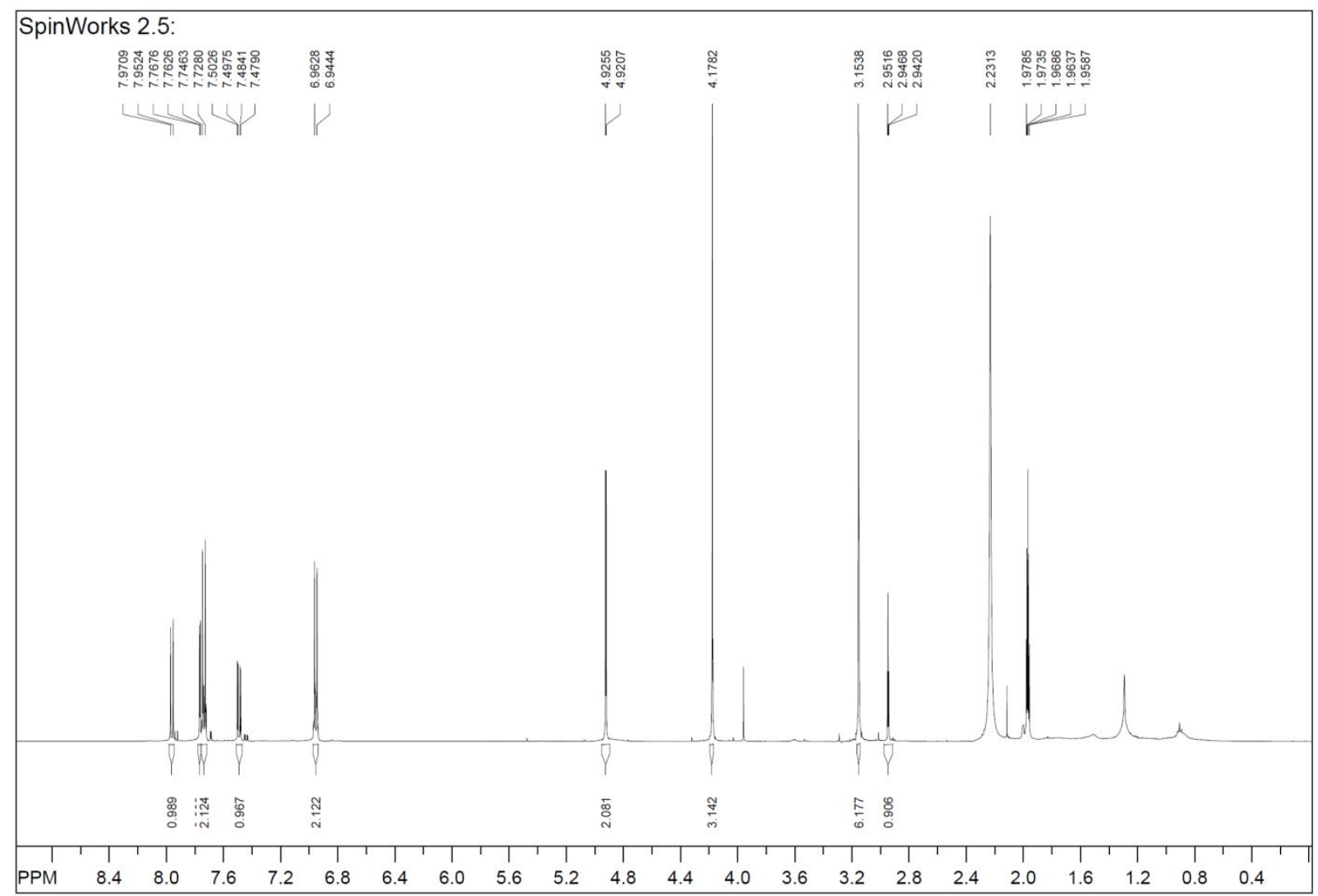

Figure S4. ${ }^{1} \mathrm{H}$ NMR spectrum of 2 . 


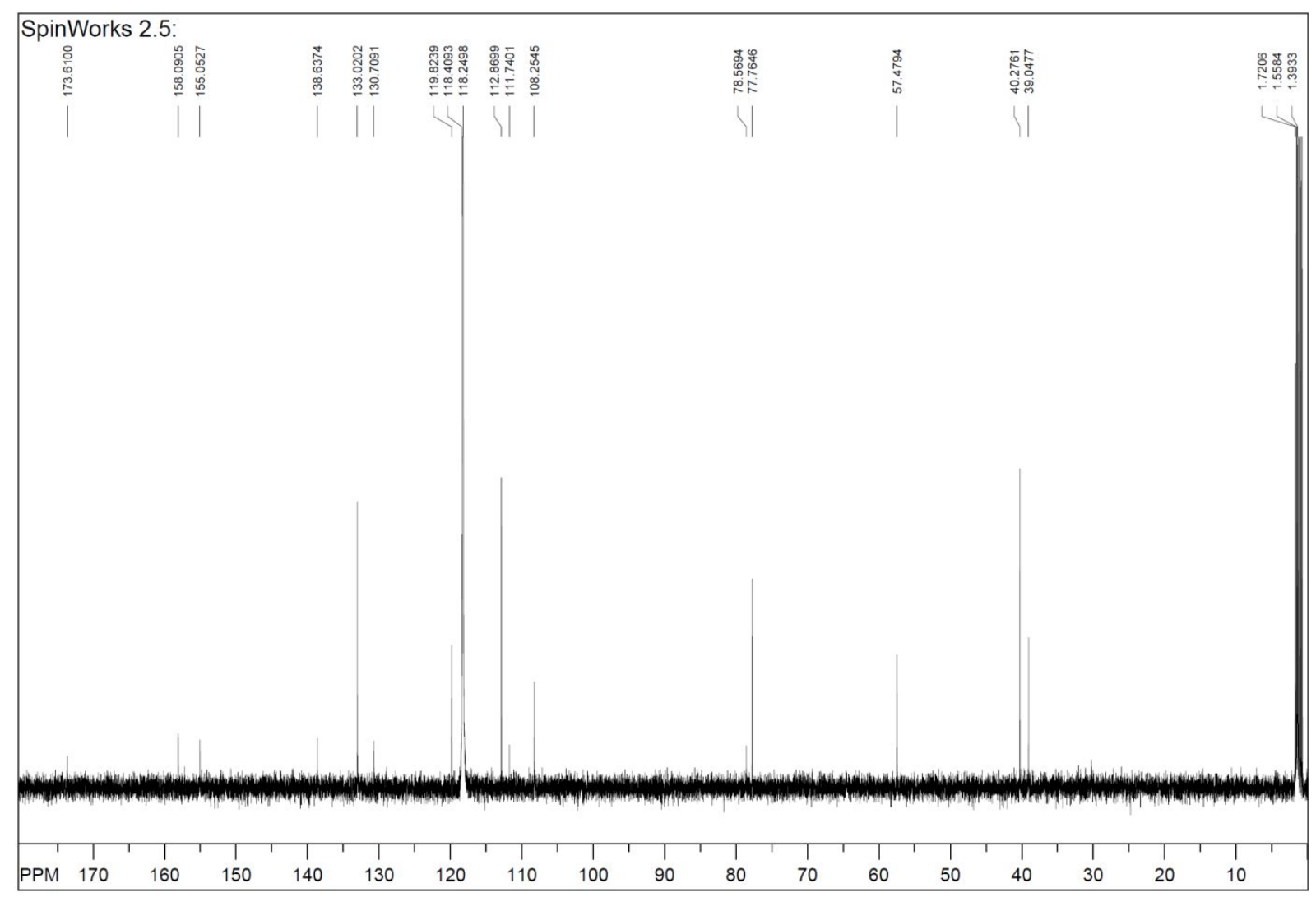

Figure S5. ${ }^{13} \mathrm{C}$ NMR spectrum of 2 .

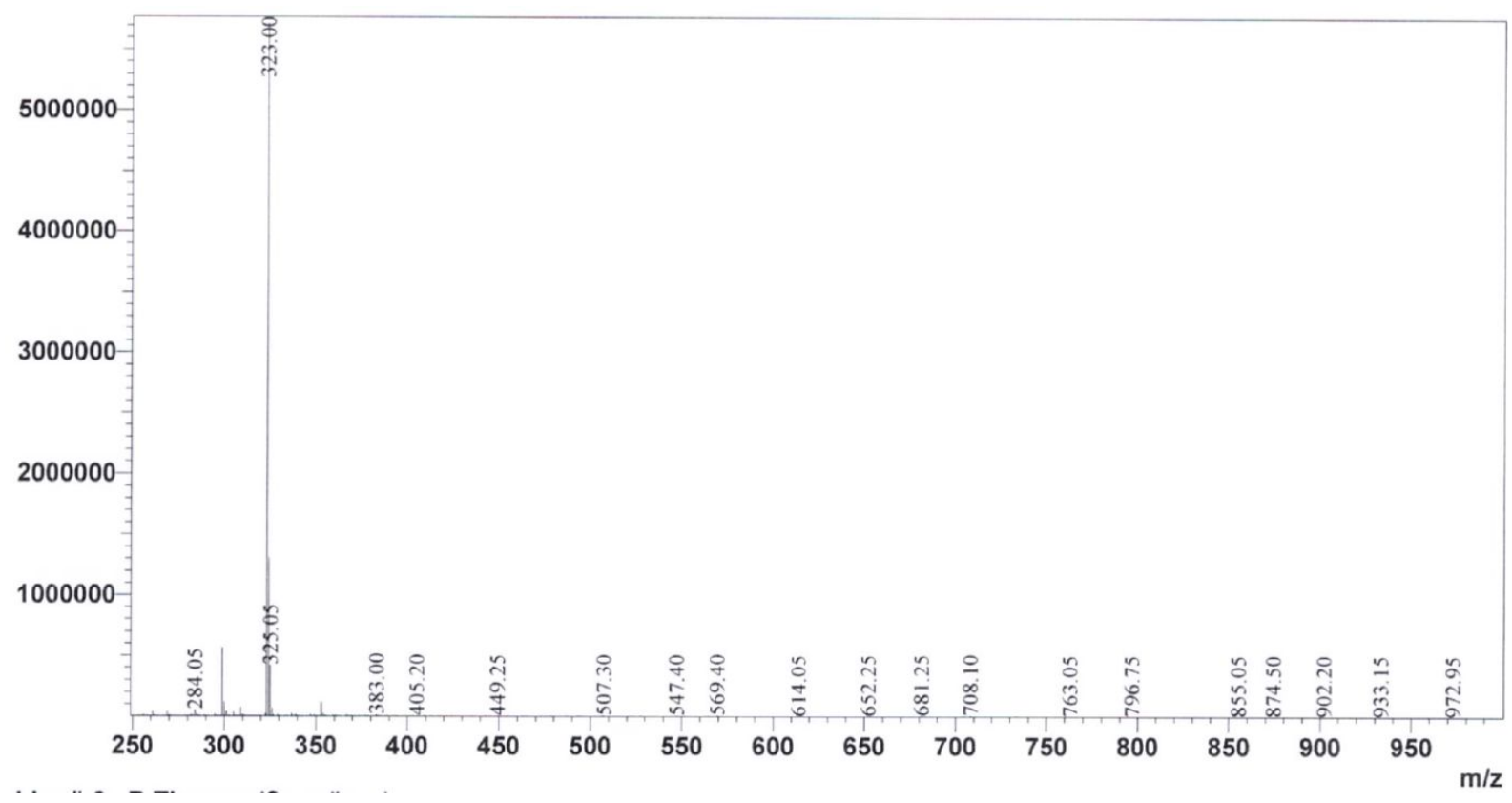

Figure S6. ESI-MS spectrum of 2. 


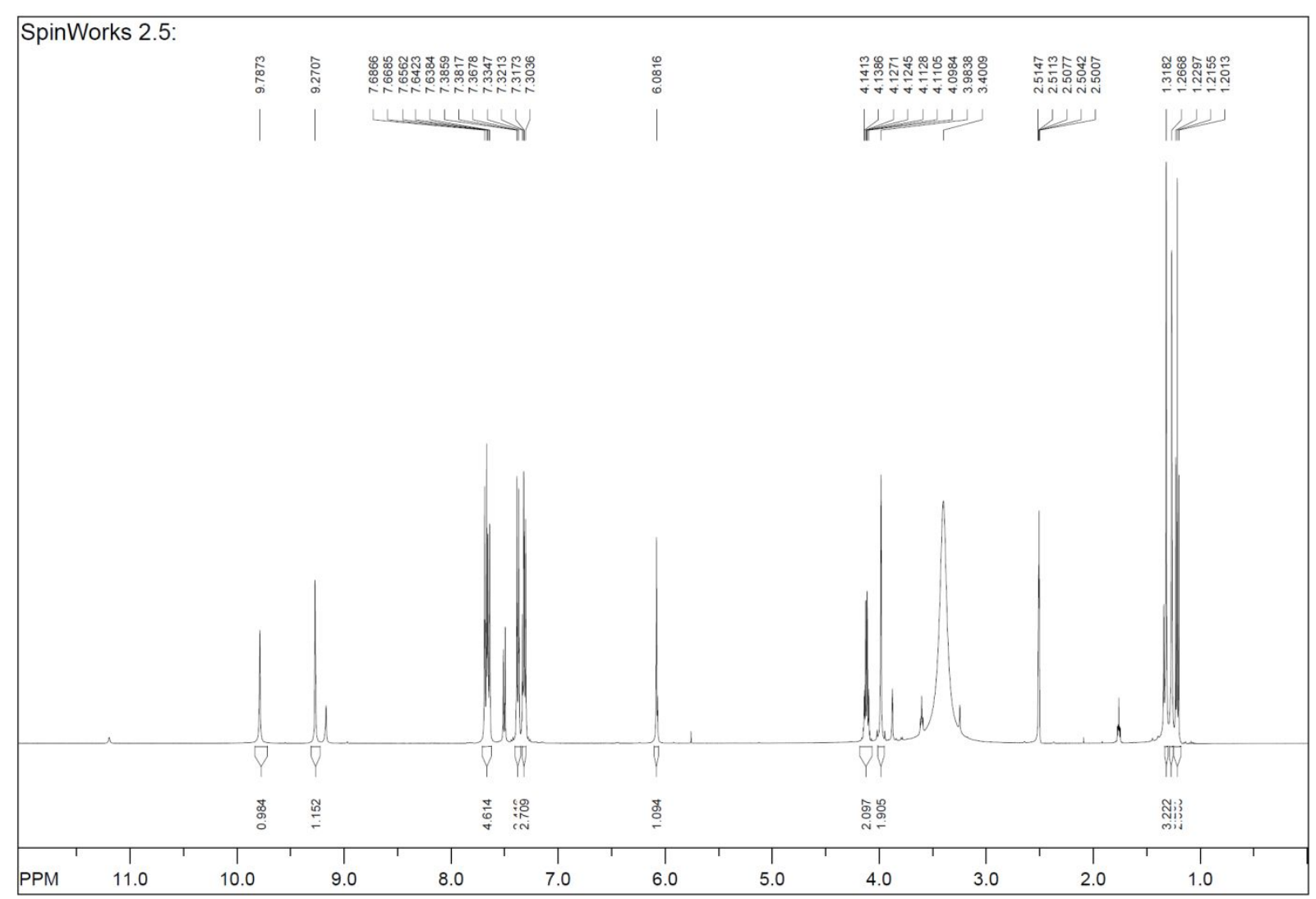

Figure S7. ${ }^{1} \mathrm{H}$ NMR spectrum of 3 .

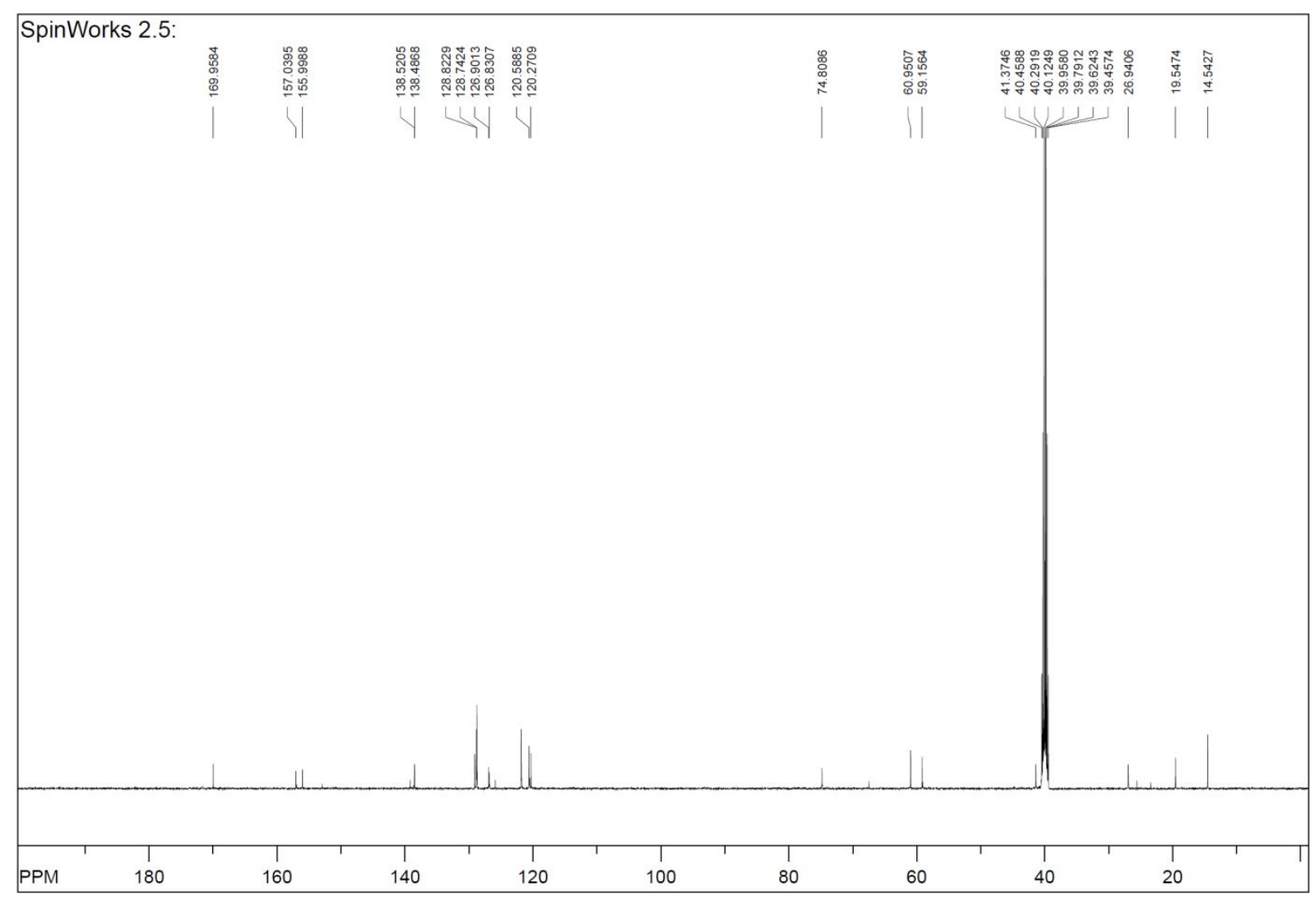

Figure S8. ${ }^{13} \mathrm{C}$ NMR spectrum of 3 . 


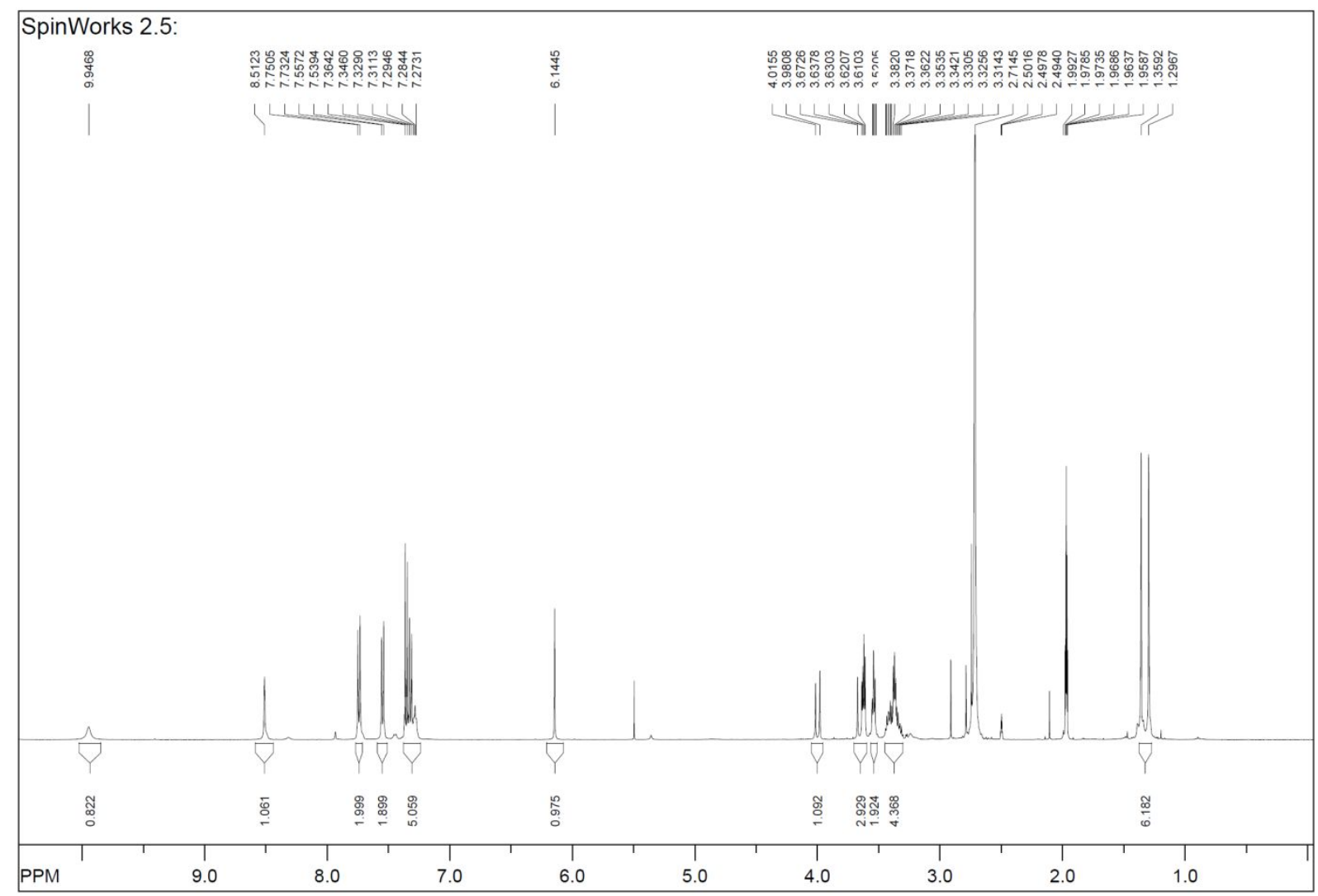

Figure S9. ${ }^{1} \mathrm{H}$ NMR spectrum of 4 .

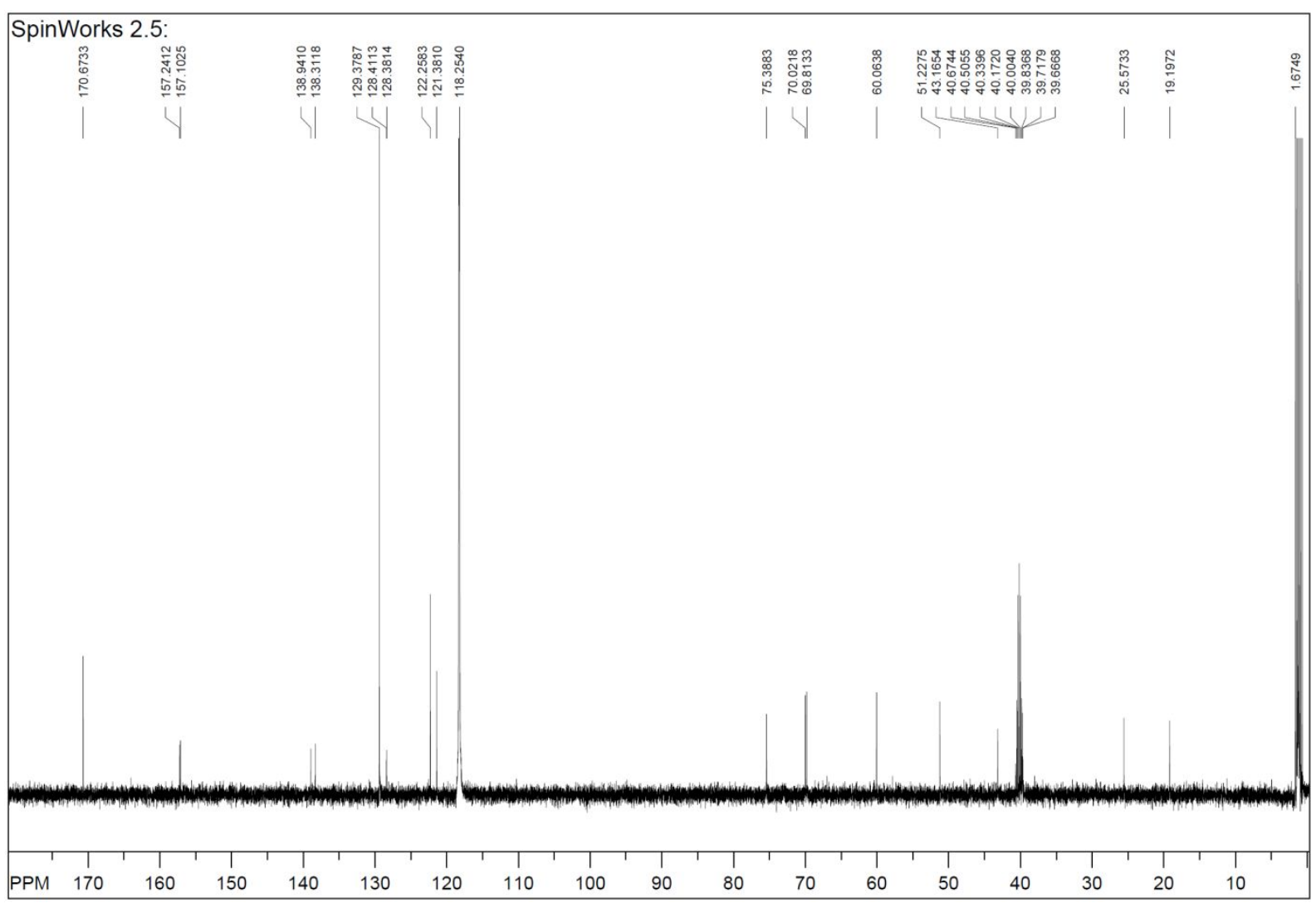

Figure S10. ${ }^{13} \mathrm{C}$ NMR spectrum of 4 . 


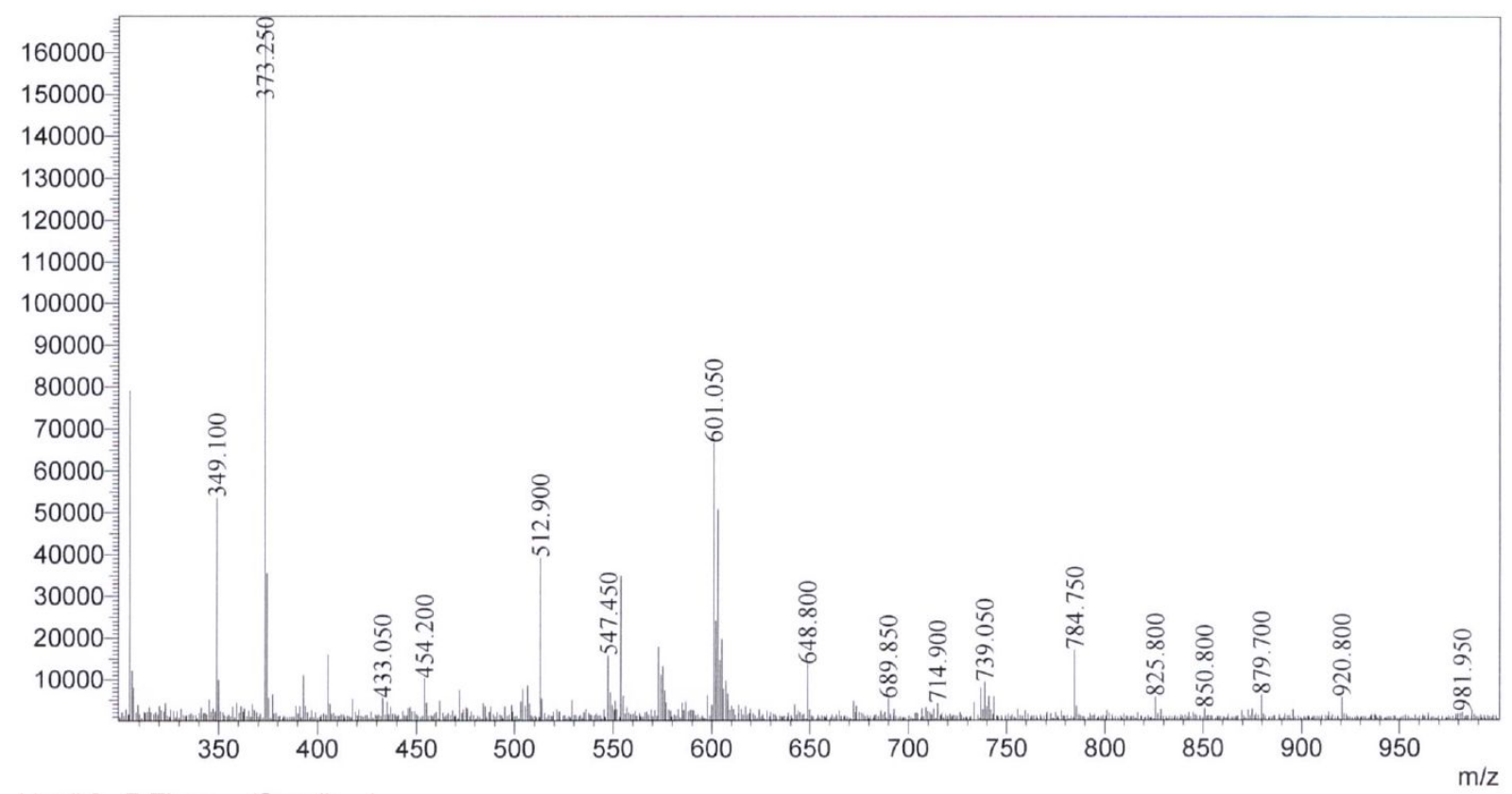

Figure S11. ESI-MS spectrum of 4.

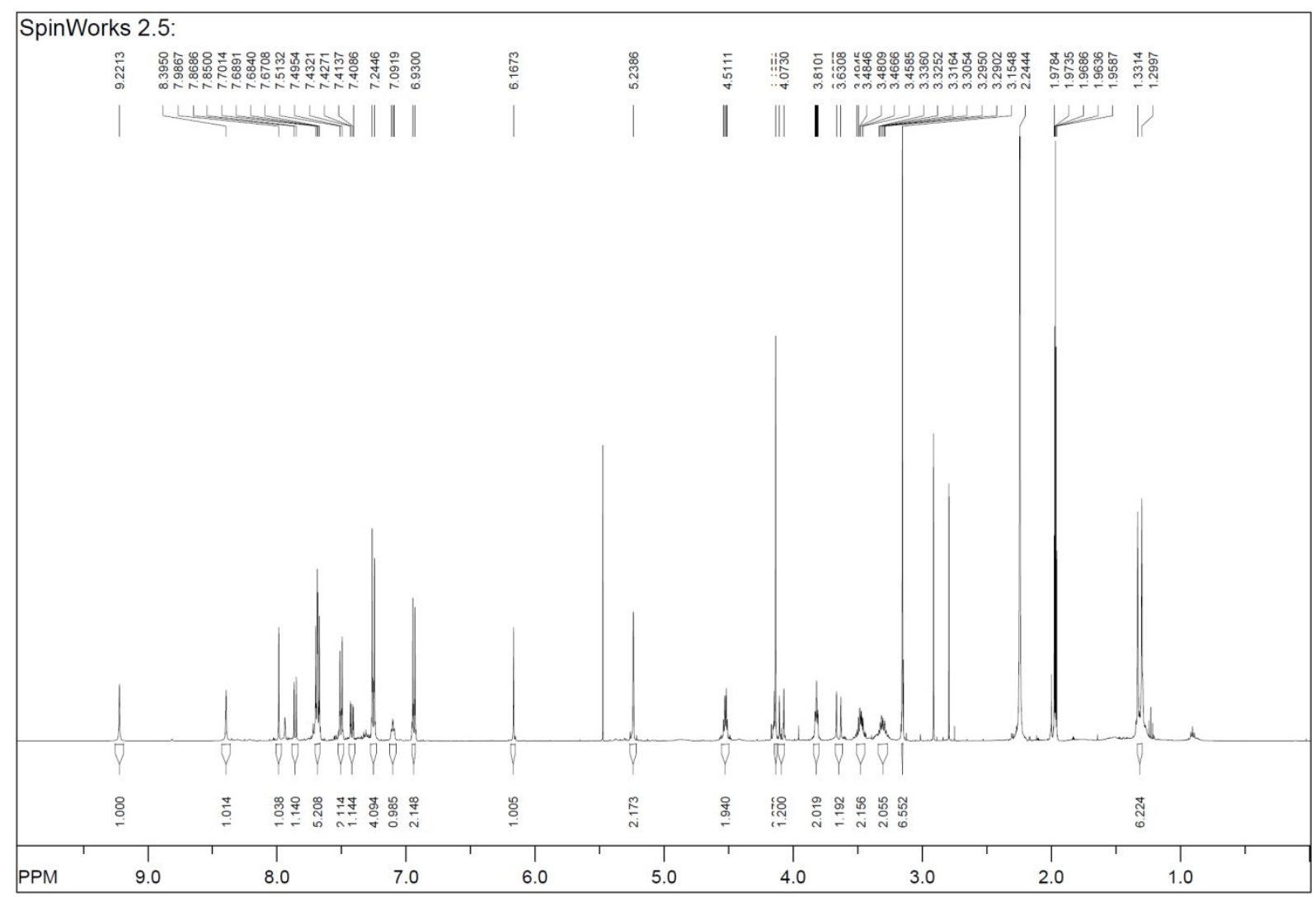

Figure S12. ${ }^{1} \mathrm{H}$ NMR spectrum of ER-ThT. 


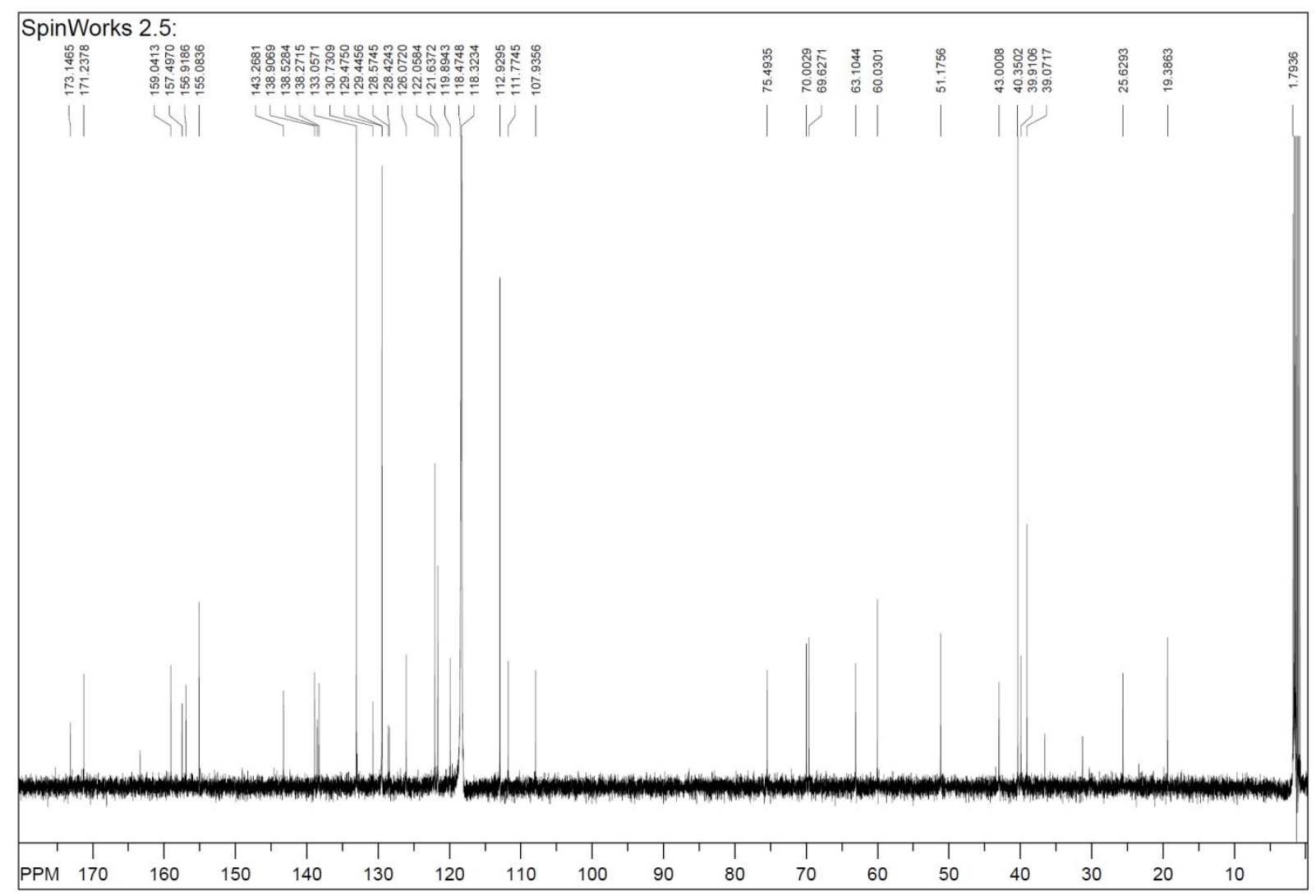

Figure S13. ${ }^{13} \mathrm{C}$ NMR spectrum of ER-ThT.

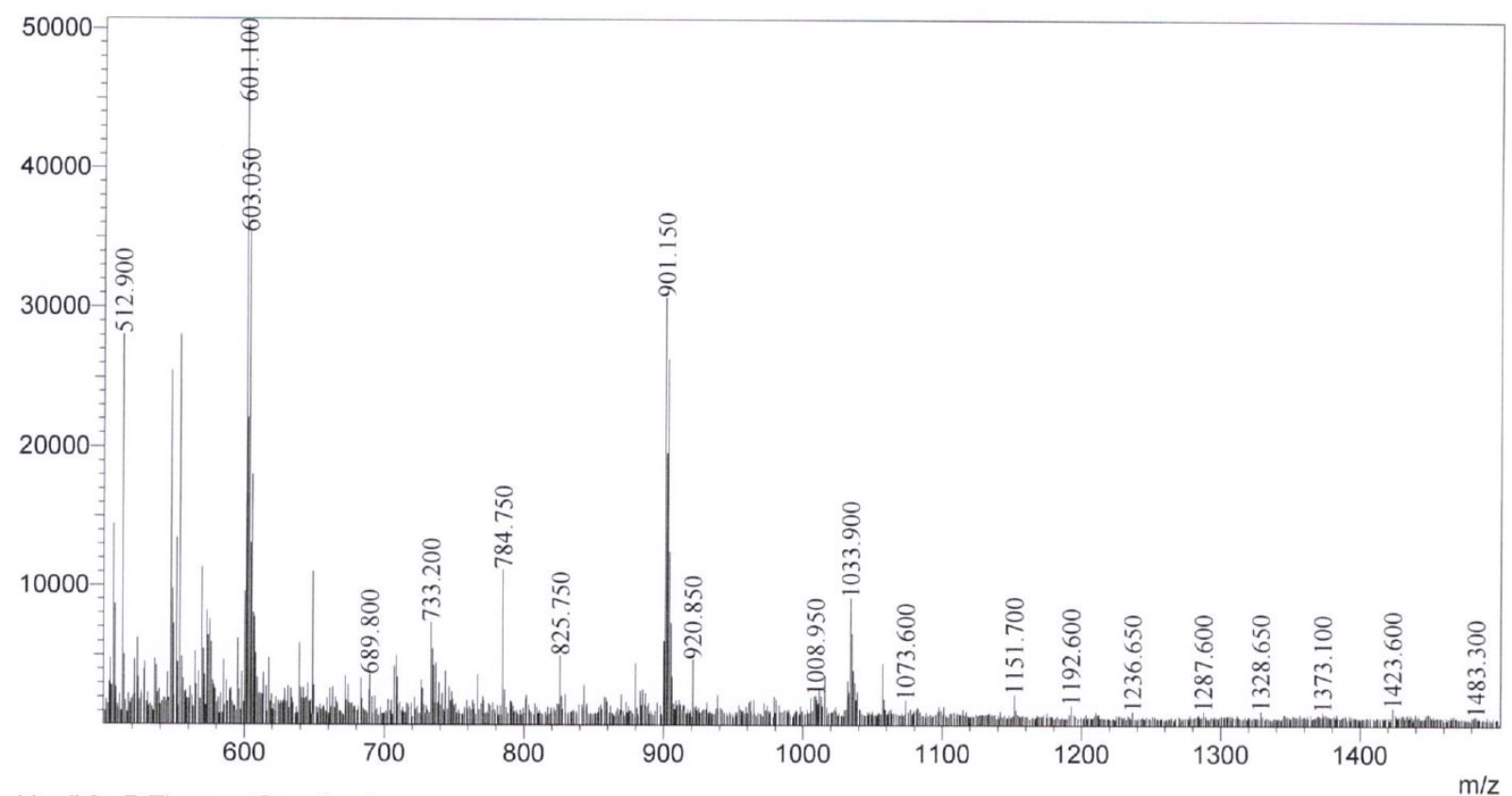

Figure S14. ESI-MS spectrum of ER-ThT. 

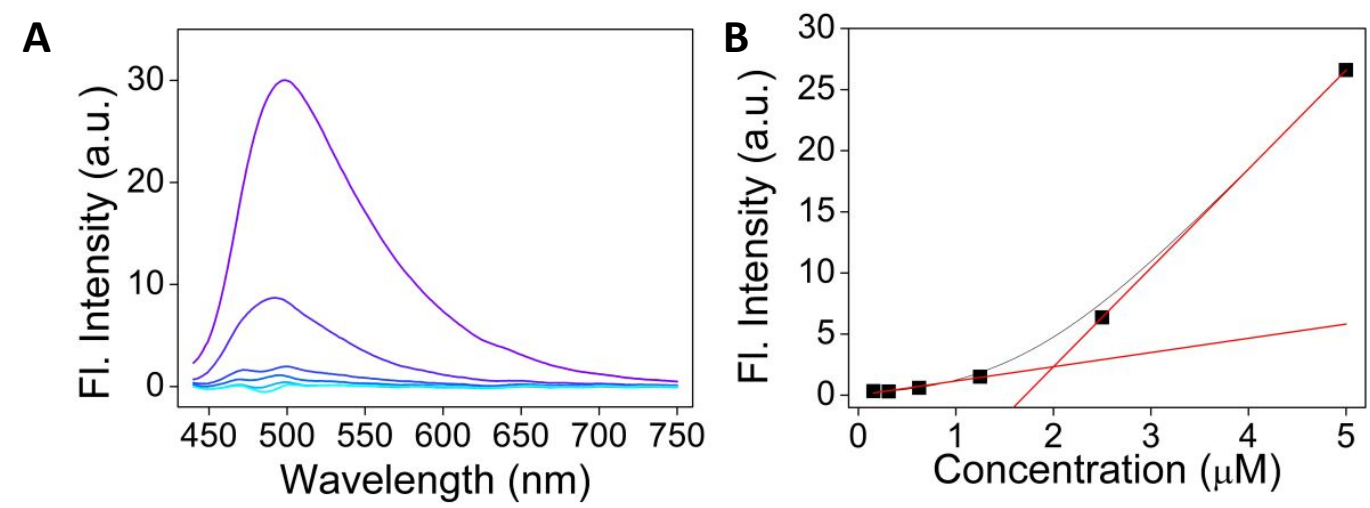

Figure S15. Fluorescence spectra with variable amounts of ER-ThT in water. (a) Concentration-dependent fluorescence spectra. (b) Plot of the emission intensity at $510 \mathrm{~nm} v \mathrm{~s}$ the concentration. The slopes (in red) of the initial phase (4 data points) and the phase for the higher concentrations ( 2 data points) indicate a critical micellar concentration at $2.01 \mu \mathrm{M}$. Emission spectra were recorded with $\lambda_{\mathrm{ex}}=420 \mathrm{~nm}$ and slit widths of $3 / 3 \mathrm{~nm}$.
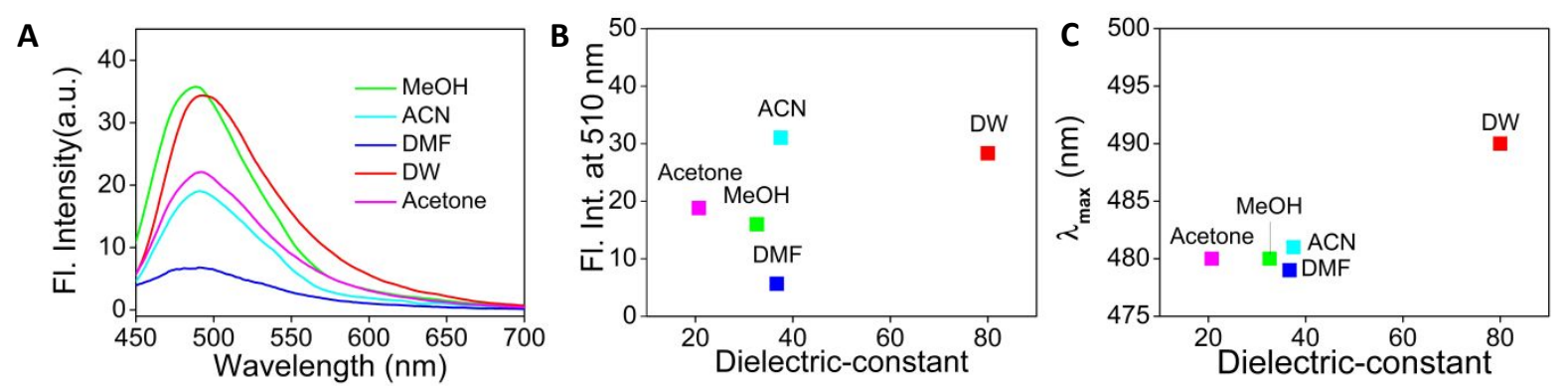

Figure S16. Effects of solvents on the fluorescence spectra of ER-ThT. (a) Emission spectra of ER-ThT $(1 \mu \mathrm{M})$ in various solvents. The intensities at $510 \mathrm{~nm}$ (b) and $\lambda_{\max , \mathrm{em}}$ (c) were plotted against the solvent dielectric constant. $\lambda_{\mathrm{ex}}=420 \mathrm{~nm}$ and slit widths of $5 / 5 \mathrm{~nm}$.

A

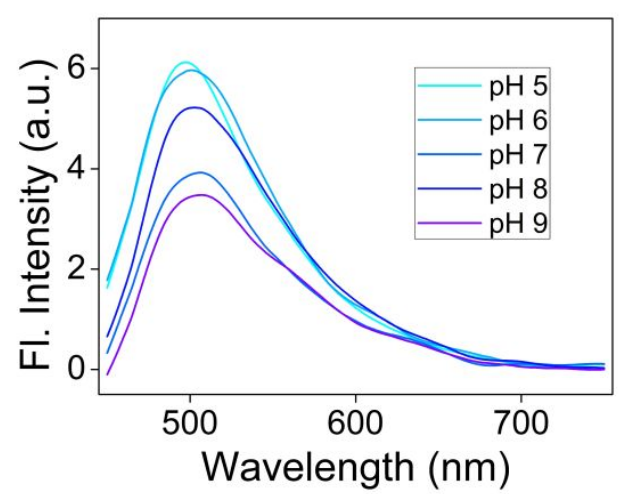

B

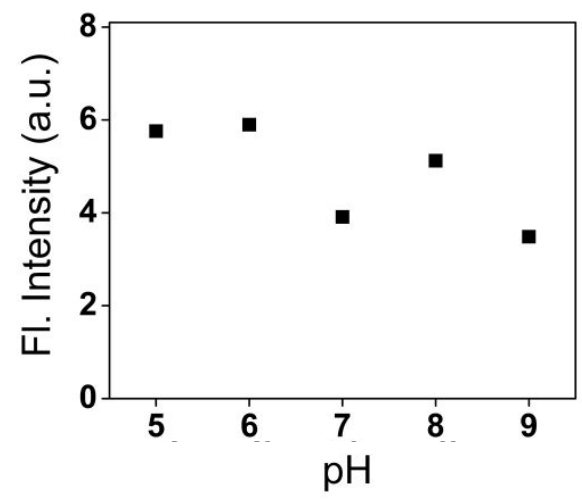

Figure S17. Influence of the pH on the fluorescence spectra of ER-ThT $(1 \mu \mathrm{M})$. (a) Emission spectra of ER-ThT at various pH levels. (b) Plot of the intensities at $510 \mathrm{~nm} v \mathrm{sH}$ values. The buffer reagents in the solution was a mixture of $20 \mathrm{mM}$ of NaOAc, HEPES and boronate. $\lambda_{\text {ex }}=420 \mathrm{~nm}$ and slit widths of $3 / 3 \mathrm{~nm}$. 

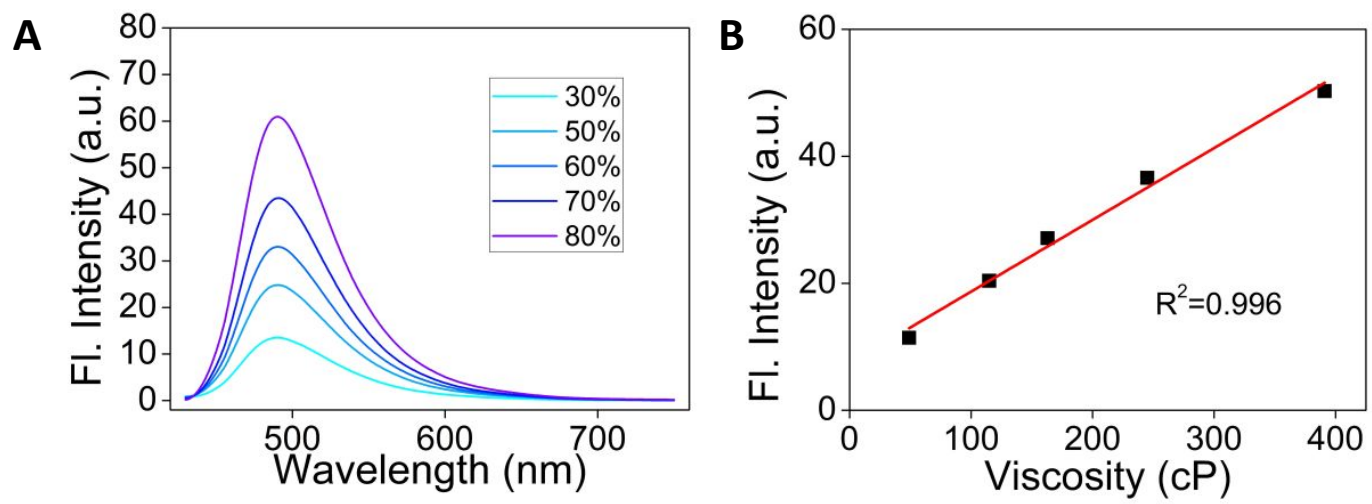

Figure S18. The effect of the viscosity on the fluorescence spectra of ER-ThT $(1 \mu \mathrm{M})$ (a) Fluorescence spectra of ER-ThT in a glycerol:glycol $(v / v)$ solution. $\lambda_{\mathrm{ex}}=420 \mathrm{~nm}$, slit width $3 / 3 \mathrm{~nm}$. (b) Plot of the fluorescence intensity at $510 \mathrm{~nm}$ against the solution viscosity.

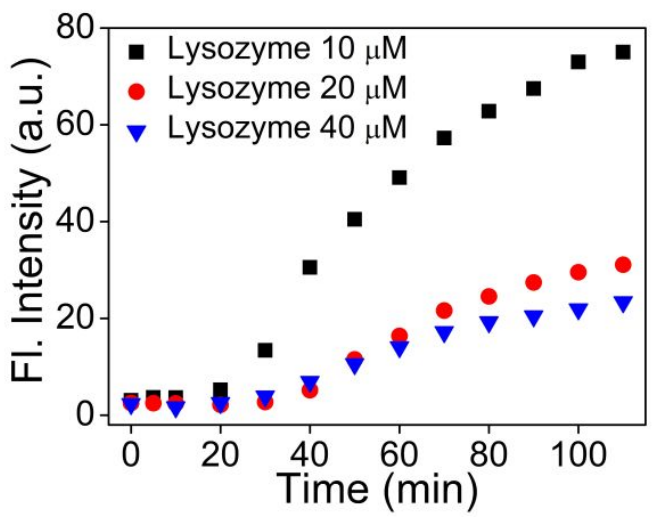

Figure S19. The effect of the amounts of lysozyme on the teme-dependent fluorescent response of ER-ThT $(1 \mu \mathrm{M})$ at $510 \mathrm{~nm}$ under DTT treatment. The intensity was immediately recorded upon addition of DTT $(10 \mathrm{mM})$ to lysozyme solutions in HEPES buffer at $37^{\circ} \mathrm{C}(20$ $\mathrm{mM}, 150 \mathrm{mM} \mathrm{NaCl}, \mathrm{pH} 7.2) . \quad \lambda_{\text {ex }}=420 \mathrm{~nm}$, slit width $3 / 3 \mathrm{~nm}$.
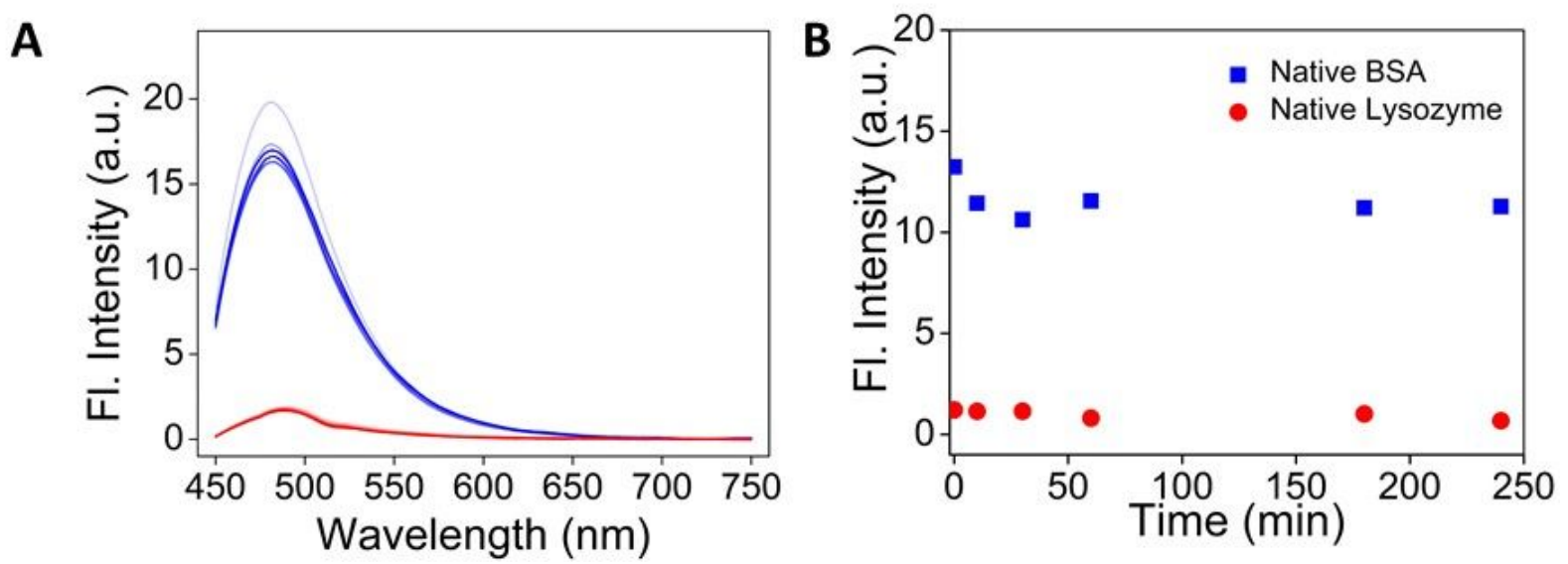

Figure S20. Time-dependent changes of (a) fluorescence spectra and (b) fluorescence intensities at $510 \mathrm{~nm}$ of ER-ThT in the presence of native lysozyme $(10 \mu \mathrm{M})$ or BSA $(10 \mu \mathrm{M})$ in a HEPES buffer $(20 \mathrm{mM}, 150 \mathrm{mM} \mathrm{NaCl}, \mathrm{pH} 7.2), \lambda_{\text {ex }}=420 \mathrm{~nm}$, slit width $3 / 3 \mathrm{~nm}$, The data were recorded at $37^{\circ} \mathrm{C}$. 


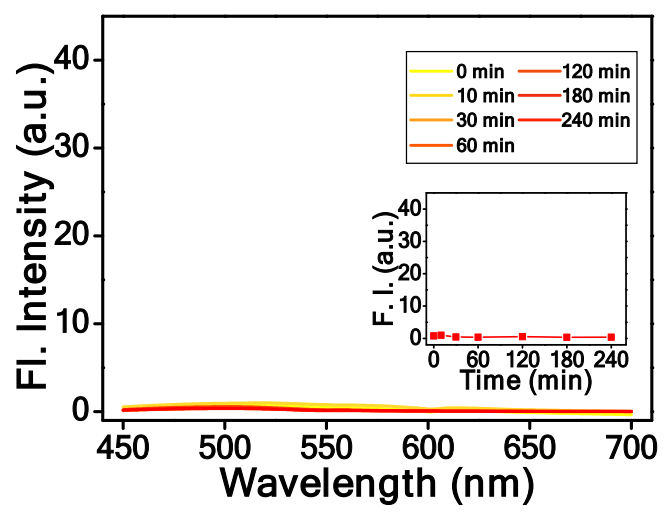

Figure S21. Fluorescence response of ER-ThT to DTT. The spectra of the probe $(1 \mu \mathrm{M})$ were measured in HEPES buffer $(20 \mathrm{mM}, 150 \mathrm{mM} \mathrm{NaCl}, \mathrm{pH} 7.2)$ at $37{ }^{\circ} \mathrm{C}$ with DTT (10 $\mathrm{mM})$. The time indicates the duration of ER-ThT co-incubation. Inset: Fluorescence intensity at $510 \mathrm{~nm}$ vs. the incubation time. $\lambda_{\mathrm{ex}}=420 \mathrm{~nm}$, slit width $3 / 3 \mathrm{~nm}$.
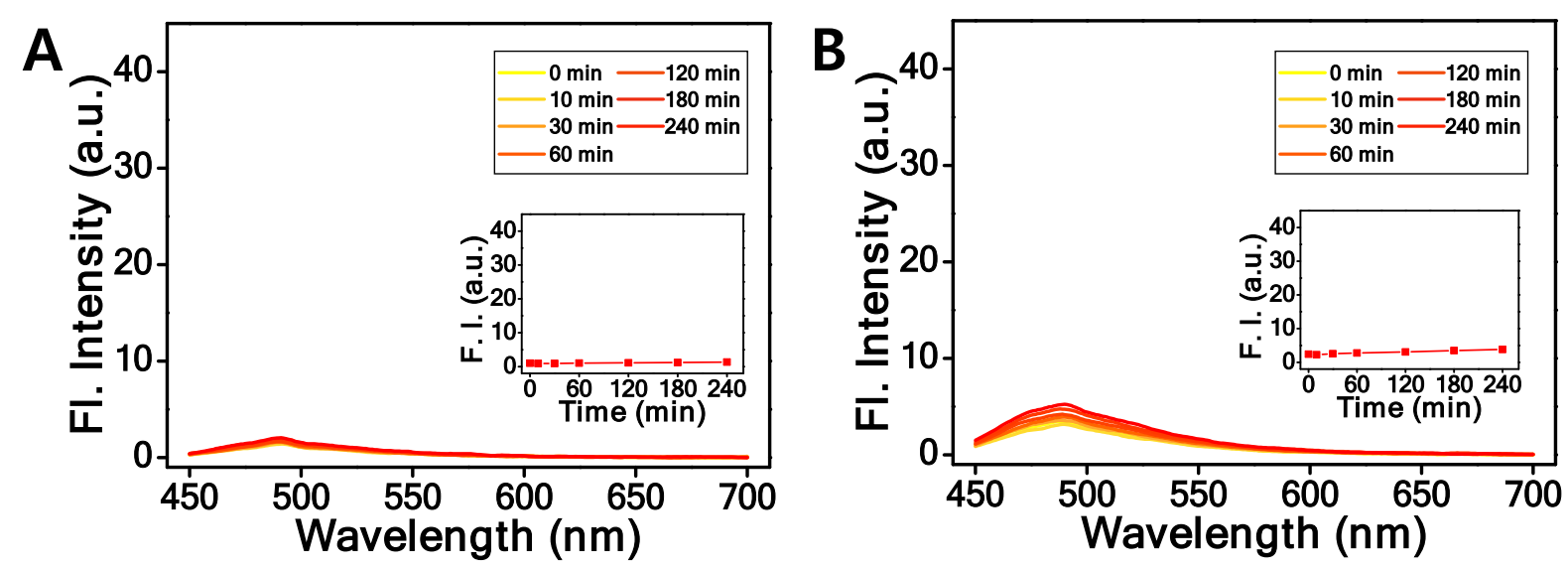

Figure S22. Fluorescence response of ER-ThT to DTT-treated lysozyme and BSA samples in the presence of a surfactant. The spectra of the probe $(1 \mu \mathrm{M})$ were measured with $10 \mu \mathrm{M}$ of lysozyme (A) and BSA (B) in HEPES buffer $(20 \mathrm{mM}, 150 \mathrm{mM} \mathrm{NaCl}, \mathrm{pH} 7.2)$ containing 10 $\mathrm{mM}$ of DTT and $0.1 \%(w / v)$ of SDS at $37{ }^{\circ} \mathrm{C}$. The time indicates the duration from the addition of DTT. The insets are the plots of fluorescence intensities at $510 \mathrm{~nm}$ vs. the incubation time. $\lambda_{\mathrm{ex}}=420 \mathrm{~nm}$, slit width $3 / 3 \mathrm{~nm}$. 


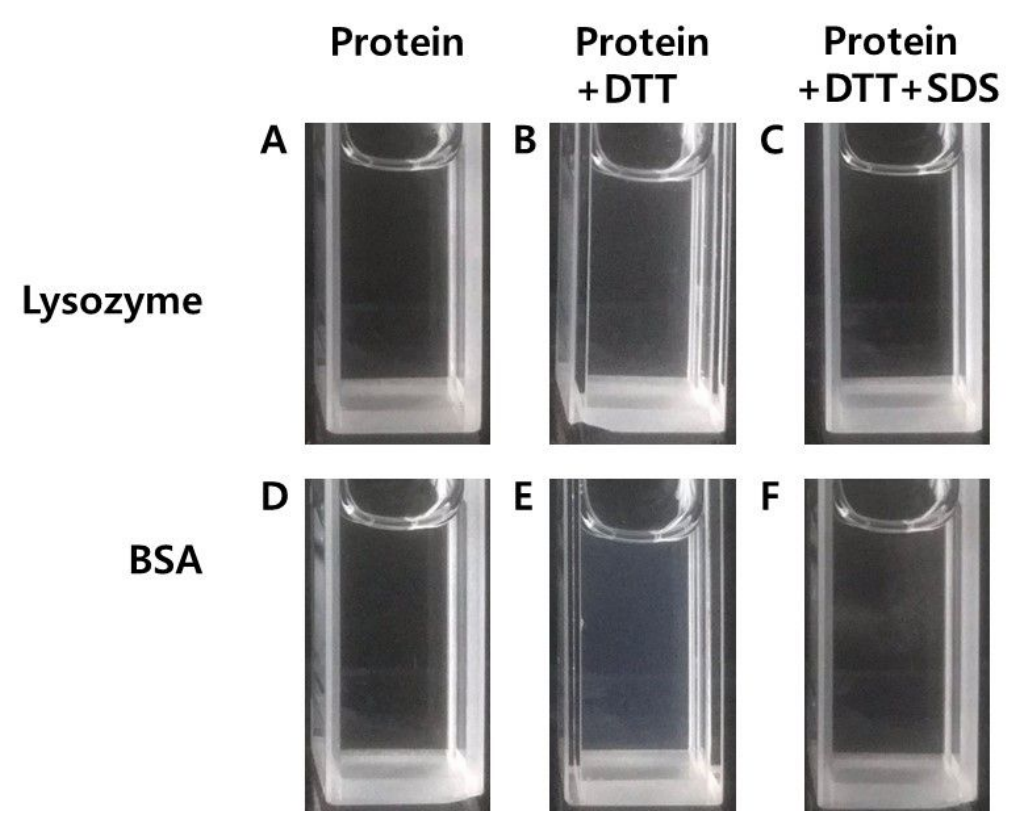

Figure S23. Protein aggregation induced by DTT. Top row: lysozyme, Bottom row: BSA. First column: proteins in a buffer solution (20 mM of HEPES and $150 \mathrm{mM}$ of $\mathrm{NaCl}, \mathrm{pH} 7.2$ ). Middle column: Following the addition of $10 \mathrm{mM}$ of DTT. Last column: Proteins treated with $10 \mathrm{mM}$ of DTT with $0.1 \%(w / v)$ SDS. The images were taken 4 hours after incubation at $37^{\circ} \mathrm{C}$.

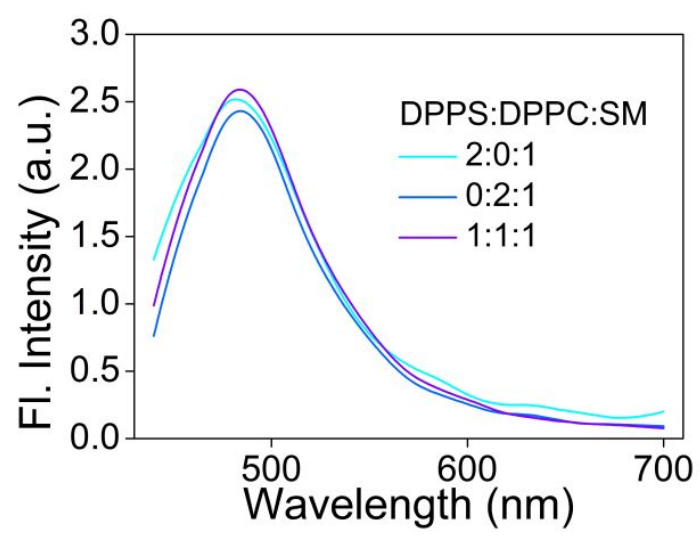

Figure S24. The effect of the polar head groups of phospholipids in liposomes on the fluorescence spectra of ER-ThT $(1 \mu \mathrm{M})$. Total lipid concentration was $9 \mu \mathrm{M}$ where the molar ratio of lipids was shown in the figure. $\lambda_{\mathrm{ex}}=420 \mathrm{~nm}$, slit width $3 / 3 \mathrm{~nm}$. 


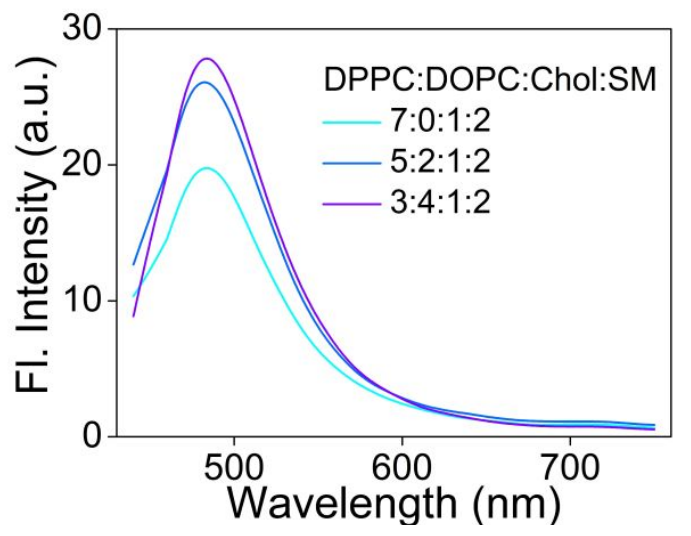

Figure S25. The effect of the degree of unsaturation of the phospholipids in liposomes on the fluorescence spectra of ER-ThT $(1 \mu \mathrm{M})$. Total lipid concentration was $9 \mu \mathrm{M}$, where the molar ratio of lipids is shown in the figure. $\lambda_{\mathrm{ex}}=420 \mathrm{~nm}$, slit width $3 / 3 \mathrm{~nm}$.

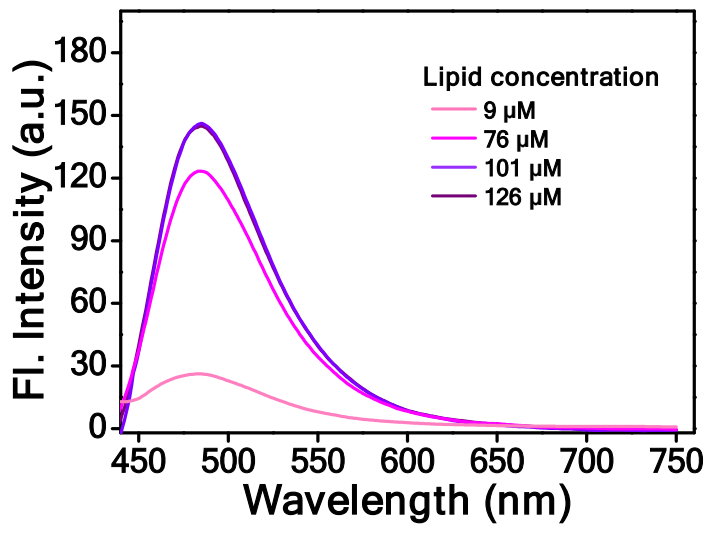

Figure S26. The effect of the amount of a liposome on the fluorescence spectra of ER-ThT $(1 \mu \mathrm{M})$. The buffer solutions are $20 \mathrm{mM}$ of HEPES and $150 \mathrm{mM}$ of $\mathrm{NaCl}$ at $\mathrm{pH}$ 7.2. The composition of the liposomes is 5:2:1:2 for DPPC:DOPC:Chol:SM. $\lambda_{\mathrm{ex}}=420 \mathrm{~nm}$, slit width $3 / 3 \mathrm{~nm}$. 


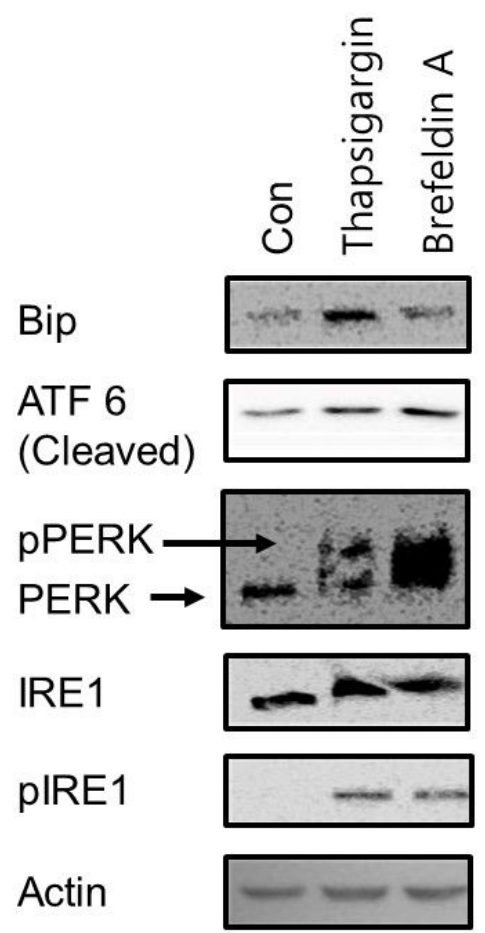

Figure S27. Effect of Thapsigargin and Brefeldin A on the expression of ER stress markers. HeLa cell lysates were prepared by cell lysis using RIPA buffer and the proteins were analyzed by Western blot in a 10\% SDS-PAGE gel. The cells were treated with $5 \mu \mathrm{M}$ Thapsigargin; or $100 \mu \mathrm{M}$ Brefeldin A 3 hours prior to cell lysis.

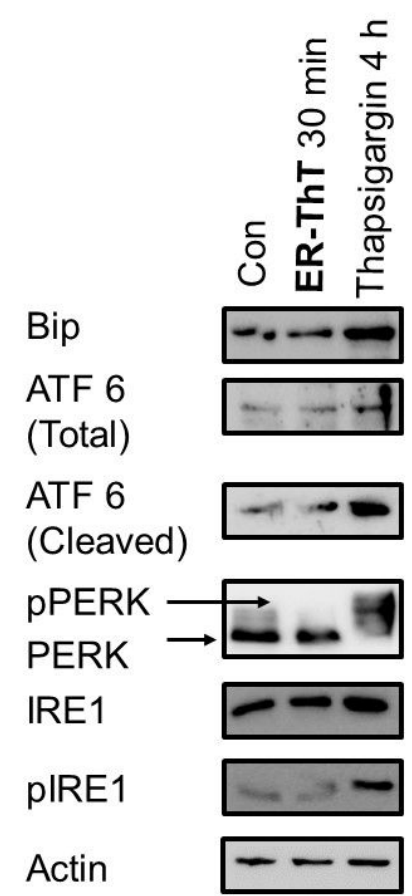

Figure S28. The effect of ER-ThT treatment on the ER stress markers in HeLa cells. The cells were treated with the probe $(1 \mu \mathrm{M})$ for $30 \mathrm{~min}$. Thapsigargin treatment $(3 \mathrm{~h})$ was used as a positive control. 

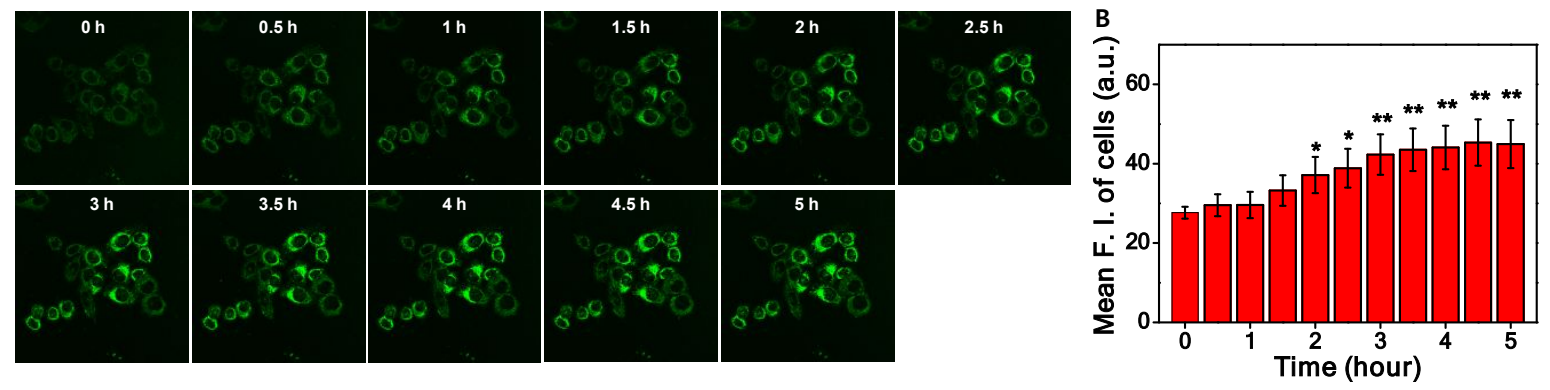

Figure S29. Temporal monitoring of ER-ThT in the Thapsigargin-mediated ER stress model in HeLa cells. (A) The cells were treated with Thapsigargin $(5 \mu \mathrm{M})$ for the indicated times and the images at the given times were taken for the cells where ER-ThT $(1 \mu \mathrm{M})$ was incubated with the cells for 30 minutes prior to the imaging. $\lambda_{\mathrm{ex}}=458 \mathrm{~nm}, \lambda_{\mathrm{ex}}=475-525 \mathrm{~nm}$ (band pass filter). (B) Mean fluorescence intensity per cell $(n=12)$ with statistical significance (Student t-test) represented as $* \mathrm{P}<0.05, * * \mathrm{P}<0.01$. Error bars depict s.e.m.
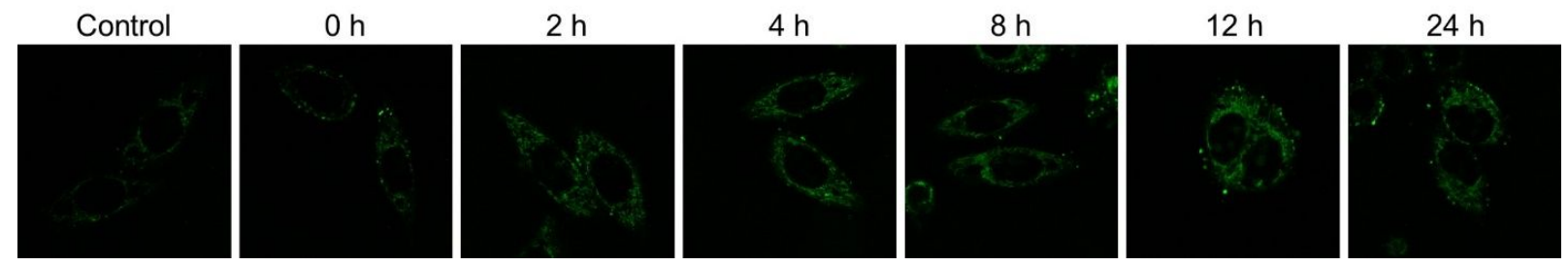

Figure S30. Temporal monitoring of ER-ThT in the Brefeldin A-mediated ER stress model in HeLa cells. The cells were treated with Brefeldin A $(100 \mu \mathrm{M})$ for the indicated times and the images at the given times were taken for the cells where ER-ThT $(1 \mu \mathrm{M})$ was incubated with the cells for 30 minutes prior to the imaging. $\lambda_{\mathrm{ex}}=458 \mathrm{~nm}, \lambda_{\mathrm{ex}}=475-525 \mathrm{~nm}$ (band pass filter). 

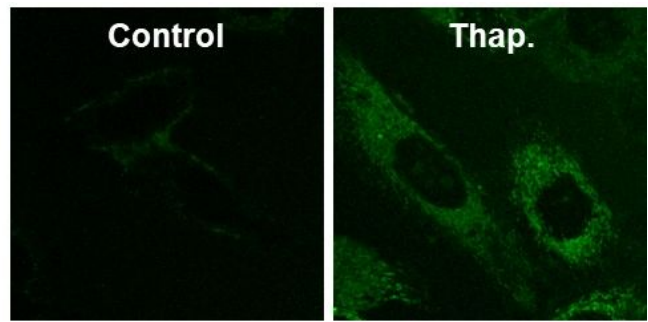

B

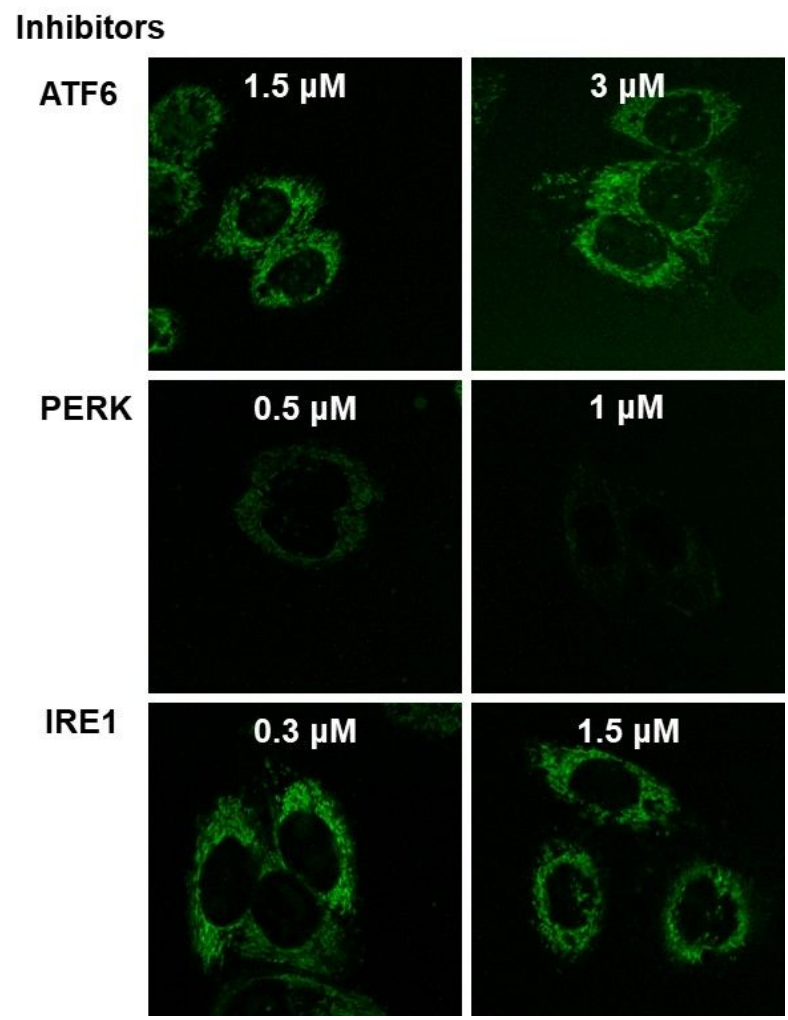

Figure S31. Effects of UPR inhibitors (Ceapin-A7; ATF6 inhibitor, GSK2656157; PERK inhibitor, Toyocamycin; IRE1 inhibitor) on ER-ThT's fluorescence in Thapsigargin-treated HeLa cells. (A) Fluorescence of cells incubated with and without Thapsigargin ( $5 \mu \mathrm{M}, 2 \mathrm{~h}$ incubation) and ER-ThT ( $1 \mu \mathrm{M}$, added 30 minutes before imaging). (B) The influence of inhibitors on ER-ThT fluorescence. Incubation times prior to imaging: ATF6 inhibitor: $2.5 \mathrm{~h}$, PERK inhibitor: $3 \mathrm{~h}$, IRE1 inhibitor $4 \mathrm{~h}$, Thapsigargin: $2 \mathrm{~h}$ and ER-ThT: 30 minutes. The confocal images were obtained using excitation at $458 \mathrm{~nm}$ with a $475-525 \mathrm{~nm}$ band pass filter. 


\section{References}

(S1) G. Bort, S. Catoen, H. Borderies, A. Kebsi, S. Ballet, G. Louin, M. Porta and C. Ferroud, "Gadolinium-based contrast agents targeted to amyloid aggregates for the early diagnosis of Alzheimer's disease by MRI", Eur. J. Med. Chem. 2014, 87, 843-861.

(S2) C. McKibbin, A. Mares, M. Piacenti, H. Williams, P. Roboti, M. Puumalainen, A. C. Callan, K. Lesiak-Mieczkowska, S. Linder, H. Harant, S. High, S. L. Flitsch, R. C. Whitehead and E. Swanton, "Inhibition of protein translocation at the endoplasmic reticulum promotes activation of the unfolded protein response", Biochem. J. 2012, 442, 639-648.

(S3) R. Ruiz-González, R. Bresolí-Obach, Ò. Gulías, M. Agut, H. Savoie, R. W. Boyle, S. Nonell and F. Giuntini, "NanoSOSG: A Nanostructured Fluorescent Probe for the Detection of Intracellular Singlet Oxygen", Angew. Chem. Int. Ed. 2017, 56, 2885-2888. 